\title{
5-1-2012
}

\section{Examining the Tax Advantage of Founders' Stock}

\author{
Gregg D. Polsky \\ University of Georgia School of Law, gregg.polsky@uga.edu \\ Brant J. Hellwig \\ Washington and Lee University School of Law
}

p bepress SSRN

\section{Repository Citation}

Gregg D. Polsky and Brant J. Hellwig, Examining the Tax Advantage of Founders' Stock, 97 lowa L. Rev. 1085 (2012),

Available at: https://digitalcommons.law.uga.edu/fac_artchop/1089

This Article is brought to you for free and open access by the Faculty Scholarship at Digital Commons @ University of Georgia School of Law. It has been accepted for inclusion in Scholarly Works by an authorized administrator of Digital Commons @ University of Georgia School of Law. Please share how you have benefited from this access For more information, please contact tstriepe@uga.edu. 


\title{
Examining the Tax Advantage of Founders' Stock
}

\author{
Gregg D. Polsky* E Brant J. Hellwig**
}

INTRODUCTION. 1087

I. Founders' Stock TranSACTIONS............................................... 1090

A. THE "THIN COMMON" VALUATION STRATEGY............................... 1090

1. The Thin Common Strategy as Normatively Acceptable

Ex Post Tax Planning? ..................................................... 1094

2. Is Current Under-Enforcement a Subsidy? ....................... 1095

B. ADJUSTABLE CONVERSION RATIOS AS HIDDEN BONUSES ................... 1095

C. "ACQHIRING"....................................................................... 1097

D. THE ISSUANCE OF FOUNDERS' STOCK GENERALLY ........................ 1099

II. Determining WHETHER A TAX AdVANTAge EXISTS ......................... 1100

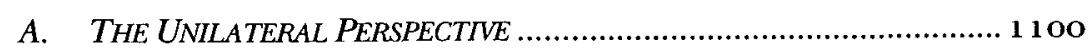

B. A PREVIEW OF THE MULTILATERAL PERSPECTIVE.............................1103

C. COMPARING FOUNDERS' STOCK TO CARRIED INTERESTS ................... 1104

III. Determining the Global TaX AdVANTAGE OR DisadVANTAGE ....... 1106

A. THE SUCCESSFUL CASES............................................................. 1109

1. Home Run ................................................................ 1109

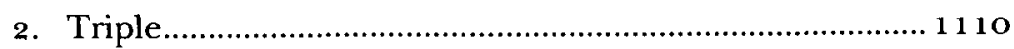

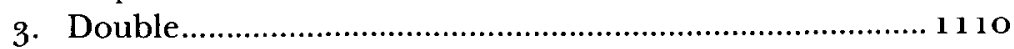

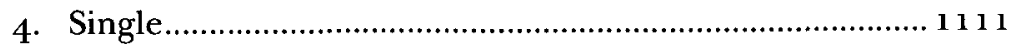

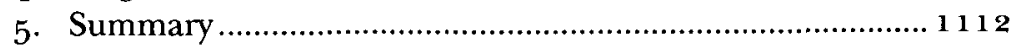

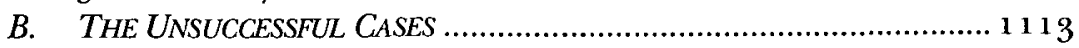

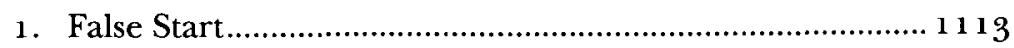

2. Strikeout............................................................... 1114

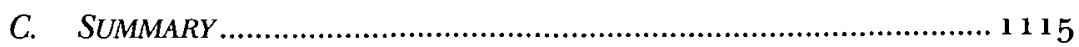

* Willie Person Mangum Professor of Law, University of North Carolina at Chapel Hill School of Law.

** Professor of Law, University of South Carolina School of Law.

The authors are grateful to Christopher Bruner, Joshua Fairfield, Martin J. McMahon, Jr., David Walker, and Ethan Yale for their informative comments on earlier drafts of the article. 
1086

IV. ASSESSMENT OF DESCRIPTIVE RESULTS 1116

A. IS THE NET TAX SAVINGS IN THE FALSE START SCENARIO A NORMATIVE TAX ADVANTAGE?. 1116

B. THE POTENTIAL FOR MARKET FAILURE. 1119

1. Questioning the Account 1121

2. Even Assuming the Account Is True, Does It Justify a Tax Response? 1123

CONCLUSION 1124

APPENDIX 1125 


\section{INTRODUCTION}

In their 2003 Harvard Law Review article, Ronald Gilson and David Schizer argued that founders' stock-the shares that founders of startup companies receive-is tax-advantaged." They described how the standard founders' stock transaction enables executives to convert compensation income otherwise taxed at ordinary income rates into stock appreciation taxed at preferential rates for capital gains, thereby reducing their tax burden by roughly sixty percent. Gilson and Schizer suggested that the tax benefits associated with the issuance of founders' stock served as a principal justification for the leading transactional form of venture capital investment. ${ }^{2}$

More recently, Victor Fleischer, already known for highlighting the carried interest tax break benefitting managers of private equity, ${ }^{3}$ characterized the tax advantage of founders' stock as a critical design flaw in the tax system-one that supplies an additional new reason to consider fundamental tax reform. 4 The idea that founders' stock is favorably taxed extends beyond the legal academy. In a 2011 editorial, Nicholas Kristof of the New York Times characterized founders' stock as being "hugely undertaxed." 5 The conventional wisdom, therefore, is that founders' stock is

1. See Ronald J. Gilson \& David M. Schizer, Understanding Venture Capital Structure: A Tax Explanation for Convertible Preferred Stock, 116 HARV. L. REV. 874, 910 (2003) (contending that the founders' stock tax advantage can be classified as a tax subsidy for high-tech startups).

2. See id. at 877 (describing the tax benefits associated with the issuance of convertible preferred stock in exchange for venture capital funding as "likely of first-order importance"); see also $\mathrm{id}$. at 889 (characterizing the tax advantage enjoyed by executives of startups as a "key reason" for the pervasiveness of convertible preferred stock in venture capital contracting).

3. See Victor Fleischer, Two and Twenty: Taxing Partnership Profits in Private Equity Funds, 83 N.Y.U. L. REV. 1, 5-6 (2008). Fleischer's article garnered attention from academics, journalists, and policymakers. E.g., Karen Burke, The Sound and Fury of Carried Interest Reform, 1 Colum. J. TAX L. 1, 2 (2010); Noël B. Cunningham \& Mitchell L. Engler, The Carried Interest Controversy: Let's Not Get Carried Away, 61 TAX L. Rev. 121 (2008); Chris William Sanchirico, The Tax Advantage to Paying Private Equity Fund Managers with Profit Shares: What Is It? Why Is It Bad?, 75 U. CHI. L. REv. 1071 , 1074 (2008); Editorial, Taxing Private Equity, N.Y. Times (Apr. 2, 2007), http://www.nytimes.com/2007/04/o2/opinion/o2mon1.html; Allan Sloan, Busting $a$ Few Blackstone Tax Myths, FORTUNE MAG. (Sept. 17, 2007), http://money.cnn.com/2007/ 09/14/news/companies/100351828.fortune/index.htm; see also DEP'T OF THE TREASURY, GENERAL EXPLANATIONS OF THE ADMINISTRATION'S Fiscal YEAR 2012 REVENUE Proposals 6162 (2012), available at http://www.treasury.gov/resource-center/tax-policy/Documents/ General-Explanations-FY20 1 2.pdf.

4. See Victor Fleischer, Taxing Founders' Stock, 59 UCLA L. REV. 6o, 69-70 (2011). Fleischer analogized the tax break afforded to founders' stock to the carried interest loophole. See Fleischer, supra note 3 , at 2 n.2. For discussion of carried interests and how they compare to founders' stock, see infra Subpart II.C.

5. Nicholas D. Kristof, Op-Ed., Taxes and Billionaires, N.Y. TIMES (July 6, 2011), http://www.nytimes.com/2011/07/o7/opinion/o7kristof.html. 
tax-advantaged, leaving only the question of whether this alleged subsidy for entrepreneurship should be eliminated. ${ }^{6}$

The conventional wisdom concerning the tax benefits of founders' stock is flawed. In the majority of cases, use of founders' stock to compensate founding executives of a startup enterprise does not generate a net tax benefit to the parties. While it is indisputably true that founders enjoy substantial tax savings when they receive stock in lieu of more traditional types of compensation due to the tax rate reduction, the consequences to all transacting parties must be considered in determining whether the arrangement enjoys an overall tax advantage. 7 If one side of a transaction receives a tax benefit from a particular structure but the other side bears an equal and offsetting tax detriment, the structure is not tax-advantaged on the whole. Rather, government revenue is constant. While the formal incidence of the tax may be skewed (i.e., fewer tax dollars from the advantaged party, more from the disadvantaged party), this is not terribly significant provided the parties can adjust their agreement to reflect this effect. ${ }^{8}$ Once a proper multilateral or joint tax perspective is taken, the issue of whether founders' stock is tax-advantaged becomes considerably more nuanced than prior commentary has suggested.

In the case of founders' stock, the startup company stands on the other side of the transaction. By issuing stock in lieu of more traditional forms of compensation, the company forfeits potentially valuable compensation

6. Compare Gilson \& Schizer, supra note 1, at 9o9-16 (contending that the tax benefits associated with the issuance of founders' stock could be understood as an unintentional tax subsidy for high-tech startup companies and proceeding to evaluate the efficiency of the de facto subsidy), with Fleischer, supra note 4 , at 68 (contending that the subsidy is unwarranted but highlighting the difficulties of eliminating the subsidy absent wholesale changes to the tax code).

7. See Jonathan Gruber, Public Finance and Public Policy 521 (2005) ("[T] he side of the market on which the tax is imposed is irrelevant to the distribution of the tax burdens."); Michael S. Knoll, The Tax Efficiency of Stock-Based Compensation, 103 TAX NOTES 203, 208 (2004) ("Whether a compensation mechanism is tax efficient should be determined from a joint contracting perspective rather than the employer's or employee's perspective alone."); David I. Walker, Is Equity Compensation Tax Advantaged?, 84 B.U. L. REV. 695, 699-700 (2004); Ethan Yale \& Gregg D. Polsky, Reforming the Taxation of Deferred Compensation, 85 N.C. L. REV. $571,5^{80}$ (2007) (explaining that "the side of the compensation arrangement on which a tax burden is imposed or a tax benefit is conferred is irrelevant when evaluating the economic burden of the tax, since the parties can adjust the nominal pretax compensation to shift the tax benefits and burdens between themselves"). For an evaluation of the tax advantage of carried interests through the use of the joint tax perspective, see Michael S. Knoll, The Taxation of Private Equity Carried Interests: Estimating the Revenue Effects of Taxing Profit Interests as Ordinary Income, $5^{\circ}$ WM. \& MARY L. REV. 11 5, 125-27 (2008) [hereinafter Knoll, Carried Interests].

8. Formal incidence is in contrast with economic incidence. The party who formally remits the tax dollars to the government bears the formal incidence of the tax. If that party shifts the burden of the tax to another party through, for example, higher prices, then the latter party bears the economic incidence of the tax. See Joy Sabino Mullane, Incidence and Accidents: Regulation of Executive Compensation Through the Tax Code, 13 LEWIS \& CLARK L. REV. $4^{8} 5,495-98(2009)$. 
deductions. Thus, while founders enjoy a tax rate reduction, the company's future expected tax liability increases. In effect, the company is foregoing future tax savings to provide the rate reduction eventually enjoyed by its executives. To determine whether founders' stock is tax-advantaged on the whole, analysts must weigh the benefit to the taxpayer from the founders' rate reduction against the cost of the company's deduction forfeiture. 9 The benefit of the company's deduction increases with the overall success of the venture. Accordingly, instances of "home run" startups-in which the tax benefits to company executives attributable to the receipt of founders' stock may appear egregious-are precisely the situations that likely generate additional revenue for the government. ${ }^{\circ}$

Furthermore, even in less successful ventures, where founders' stock may produce an overall tax advantage, this benefit merely mitigates the tax law's overly harsh treatment of losses suffered by the company. Thus, by widening the perspective beyond the particular transaction at issue and considering the lifetime tax treatment of the startup company, the advantage for founders' stock turns out to be a partial move towards the optimal treatment of tax losses, rather than a stand-alone tax benefit that Congress should eliminate.

The taxation of founders' stock is a particularly timely topic. The social buying site Groupon recently went public with the closing share price indicating a company valuation of $\$ 16$ billion, ${ }^{11}$ and the gaming company Zynga followed with a public offering that valued the company at $\$ 7$

9. While prior discussion of the tax-advantageousness of founders' stock has mentioned the tax consequences to the startup company, the discussion has not been complete. Gilson and Schizer mention the lost tax deductions in a few footnotes, see Gilson \& Schizer, supra note 1, at $890 \mathrm{n} .57,895 \mathrm{n} .68 \& 897$ n.74, and they claim that the effect of the lost deductions will be minimal because startups typically realize significant losses in early years. We discuss the effect of delayed utilization of losses (and the possible expiration or limitation of losses) in depth in Part III. Fleischer addresses the joint tax perspective in three pages of discussion but ultimately dismisses its usefulness based on doubts that the market can effectively value tax losses in pricing the company's stock. We address this argument in Subpart IV.B.

10. See Calvin H. Johnson, Why Do Venture Capital Funds Burn Research and Development Deductions?, 29 VA. TAX REV. 29, 69 (2009) ("Employee capital gain is a money-losing strategy for a wide range of assumptions."). In this regard, if the tax rate reduction enjoyed by founding executives as a result of being compensated through the receipt of stock truly serves as an effective subsidy for entrepreneurial activity, it is a remarkable subsidy from the government's standpoint. Rather than representing an effective expenditure of government resources, the subsidy could prove to be revenue enhancing, even when viewed in isolation (that is, without considering long-term economic effects attributable to potentially increased economic activity). Rather than being funded by the government, the cost of the subsidy would be supplied by the parties who bear the burden of the increased tax liability of the corporate employer.

11. See Shayndi Raice \& Randall Smith, Groupon IPO Cheers Valley, WaLL ST. J. (Nov. 5, 2011 ), http://online.wsj.com/article/SB 10001424052970203716204577017773545604142.html. 
billion. ${ }^{12}$ Additionally, Facebook is expected to go public this year, possibly at a whopping valuation of $\$ 1$ oo billion. ${ }^{3}$ These and other similar offerings will generate considerable publicity for a number of twenty-something billionaires, led by Mark Zuckerberg with his reported $\$ 13.5$ billion of wealth. ${ }^{14}$ Combined with the focus by policymakers on deficit reduction, publicity of this sort is sure to spur calls for reforming the tax break for founders' stock. In fact, the calls have already begun. ${ }^{15}$

This Article proceeds in four parts. Part I describes the transactions that give rise to the purported benefit of founders' stock. It describes the nowfamiliar transactions discussed by Gilson, Schizer, and Fleischer and also identifies other venture capital structures that generate similar tax results. Part II describes the claimed tax advantage of founders' stock and explains why that claim is based on an unduly narrow view of the transaction. Part II also illustrates why founders' stock is not analogous to the carried interest tax benefit in the private equity setting, despite their superficial similarity. Part III uses the multilateral tax perspective to show that, in many situations, founders' stock is not tax-advantaged. Part IV then goes on to explain why, even in those situations in which founders' stock is tax-advantaged, the tax benefit should be viewed as mitigating an unwarranted tax penalty. Part IV also considers, but ultimately rejects, arguments that the joint tax perspective is inapposite in this setting.

\section{FOUNDERS' STOCK TRANSACTIONS}

\section{A. THE "THIN COMMON" VALUATION STRATEGY}

Venture capital financing of startup ventures typically is structured to permit the founders of the company to place an artificially low value on the stock issued to them as part of the transaction. ${ }^{16}$ The artificially low valuation permits the founders to take the position that they have provided full consideration for the stock through their relatively modest property contributions to the reconstituted company. Thus, even though the founders will continue to provide services to the company (often their stock

12. Eveyln M. Rusli, Zynga's Value, at $\$ 7$ Billion, Is Milestone for Social Gaming, DEALBOOK (Dec. 15, $2011,8: 56$ PM), http://dealbook.nytimes.com/2011/12/15/zynga-raise-1-billion-in$\mathrm{i}-\mathrm{p}-\mathrm{o} /$.

13. See Nathan Olivarez-Giles, Facebook IPO: Could Facebook Be Worth More than \$Ioo Billion?, L.A. TIMES (June 13, 2011 , 3:29 PM), http://latimesblogs.latimes.com/technology/ $2011 / 06 /$ facebook-ipo-value.html. For perspective, consider that Google's 2004 initial public offering valuation was $\$ 27$ billion. See Evelyn M. Rusli \& Michael J. de la Merced, Groupon Plans I.P.O. with $\$ 30$ Billion Valuation, DEALBOOK (June 2, 2011, 9:31 PM), http://dealbook. nytimes.com/2011/o6/o2/groupon-files-to-go-public/.

14. See Mark Zuckerberg, FORBES (Nov. 2011), http://www.forbes.com/profile/markzuckerberg/.

15. See Kristof, supra note 5 .

16. See generally Gilson \& Schizer, supra note 1. 
is restricted to guarantee their future services), the founders report no compensation income as a result of the transaction. ${ }^{17}$ In the absence of the artificially suppressed value placed on their shares, the founders would have realized compensation income equal to the amount of the bargain element. ${ }^{18}$ This compensation income would be subject to federal income tax at rates up to $35 \%$ and to employment taxes at a rate of $2.9 \% .{ }^{20}$ Thus, if the structure of the venture capital financing transaction-often referred to as the "thin common" strategy-works as intended, the founders are able to avoid federal taxes that would apply at a combined $37.9 \%$ rate on the bargain element inherent in their stock purchase. The compensation income that is avoided in this manner will be realized only if and when the founders dispose of their stock. Importantly, at that point, the deferred income will be subject to the preferential tax rate afforded to long-term capital gains, which presently stands at $15 \% .^{21}$

To illustrate the mechanics of this structure, consider the following hypothetical used by Fleischer. ${ }^{22}$ Mark and Eduardo form a new business with each owning half of the enterprise. At some point, a venture capital fund ("VC") offers to contribute $\$ 5,000$, ooo to the business in exchange for a one-third stake in the enterprise, an offer that Mark and Eduardo accept. The deal implies a $\$ 10,000$,ooo value on Mark and Eduardo's combined share of the business. ${ }^{23}$

17. See I.R.C. $\S_{3}$ (a) (2006) (requiring taxpayers to report income when they receive, in connection with the performance of services, property that is worth more than they pay for it). Founders' stock is typically unvested; the impact of this is discussed infra note 27 .

18. See I.R.C. $\$ 8_{3}$ (a) (requiring taxpayers to report the bargain element in compensatory transfers of property as income). The bargain element is the difference between the fair market value of property and the price paid by service providers for the property.

19. See id. $\S 1$ (i) (2) (providing for maximum rates of $35 \%$ on ordinary income).

20. See id. $\$ 3101(b)(6)$ (imposing Medicare tax on wages at a rate of $1.45 \%$ on employees); $i d . \S 3111(\mathrm{~b})(6)$ (imposing Medicare tax on wages paid at a rate of $1.45 \%$ on employers). The combined effective rate of employment taxes likely will be lower than the full $\mathbf{2 . 9 \%}$ nominal rate, as an employer may deduct its portion of the Medicare tax. Hence, if the employer is profitable and the value of the deduction is based on a $35 \%$ marginal corporate income tax rate, the combined effective rate of employment tax would be $2.4 \%([1.45 \%]+$ $[1.45 \% \times 0.65])$. However, to avoid the prospect of understating the benefit to executives of being compensated through the issuance of founders' stock (due to the present value of the employer's deduction being worth less than thirty-five cents on the dollar), we err on the high side by using the statutory $2.9 \%$ rate (which assumes the employer's deduction is worthless).

21. See id. $\$ 1(\mathrm{~h})$ (providing a general maximum capital gains rate of $15 \%$ ). In addition, if the founder holds the stock until death, the stock's basis will be stepped-up to fair market value, thereby avoiding tax on the gain entirely. See $i d$. $\$ 1014$. Furthermore, a portion of the gain (if recognized during the founders' life) may be eligible for special tax treatment under $\$ 1202$.

For discussion of $\$ 1202$, see infra note 64 .

22. See Fleischer, supra note 4 , at $70-74$.

23. This is because VC is willing to pay $\$ 5,000,000$ for a one-third stake, the overall enterprise value is implied to equal $\$ 15,000,000$, and Mark and Eduardo's collective share of the business (after contribution by VC) is $66.7 \%$. See Johnson, supra note 10 , at 65 (noting that arm's length funding amounts imply the value of the founders' shares). 
To consummate the investment by VC, a new corporation ("Newco") is formed. VC contributes the $\$ 5$ million cash, but instead of simply receiving one-third of Newco's shares, it receives preferred stock that is convertible into one-third of Newco's common shares. The use of convertible preferred stock provides VC a measure of downside protection: if the company does not do well, the liquidation preference gives $\mathrm{VC}$ priority relative to the common shareholders if the company liquidates. Whether this liquidation preference is important to venture capital firms is unclear, ${ }^{24}$ but the liquidation preference definitely facilitates tax planning for the founders. ${ }^{25}$ If Newco issued identical types of shares to both VC and the founders, the price paid by VC ( $\$ 5,000$,ooo for one-third of the shares) would set the fair market value of the shares issued to Mark and Eduardo. Because Mark and Eduardo do not contribute nearly this amount to the company, the transaction would yield significant amounts of compensation income for them. Yet the issuance of convertible preferred stock to VC obscures the fair market value of the common shares issued to Mark and Eduardo. In particular, Mark and Eduardo will claim that their common shares should be valued based on the amount they would receive upon an immediate liquidation of the company. The residual distribution paid on their common shares will be relatively insignificant because the preferential liquidating distribution to VC will largely consume the entity's liquid assets and the liquidation itself will likely extinguish the intangible value of the enterprise. ${ }^{26}$ So long as Mark and Eduardo supply this relatively small liquidation value-say, $\$ 25$, 000 each-for their common shares upon formation, they can contend that they have paid full value for their stock. If the Internal Revenue Service ("IRS") does not successfully challenge the use of liquidation valuation in this setting, ${ }^{27}$ Mark and Eduardo would realize no

24. See Gilson \& Schizer, supra note 1 , at $88_{3}$ (concluding that while the "liquidation preference could have economic significance in some cases, [it] often proves insignificant"). Gilson and Schizer address other nontax features of the convertible preferred stock and conclude that their importance to venture capital firms is questionable. See id. at $881-89$.

25. See id. at $889-97$.

26. Congress is not unfamiliar with the use of liquidation rights relating to preferred stock to suppress the value of the transferred common interest. In the context of family-owned corporations, Congress has addressed the use of liquidation preferences to suppress the gift tax value of transferred common stock through the enactment of $\S 2701$. In general terms, the statute assigns a zero value to liquidation rights held by senior family members of a controlled corporation while also assigning to the residual common interest a floor value of $10 \%$ of the total value of all classes of equity. See I.R.C. $\$ 2701$ (a) (3) (A), (a) (4).

27. We do not mean to suggest that the use of liquidation value in this setting is appropriate. Rather, this valuation method is "economically naive, to say the least," because it ignores the significant option value inherent in an on-going enterprise. Gilson \& Schizer, supra note 1 , at 899 . Calvin Johnson has gone so far as to suggest that the intentional undervaluation of the stock received by the founders as part of this transaction exposes the founders to charges of criminal tax evasion. See Johnson, supra note 10, at 66 (noting the federal sentencing guidelines for underreporting of this magnitude and noting that the founder-employees will 
compensation income upon formation of Newco. ${ }^{28}$ Any disguised compensation income would be taxed to Mark and Eduardo only upon the sale of their stock, at which point the income would be taxed at preferential capital gains rates.

In their Harvard Law Review article, Gilson and Schizer explain that the liquidation preference in the convertible preferred stock VC purchases has little independent value to $\mathrm{VC}$ because it will rarely come into play. ${ }^{29}$ They note that the vast majority of startups either experience sufficient success to cause venture capitalists to elect to convert their investment into common stock or burn through all of their cash before ultimately failing. $3^{\circ}$ In either case, the liquidation preference proves irrelevant. Put differently, rarely will a startup's performance be sufficiently "sideways" (as opposed to steeply up or steeply down) for the liquidation preference to be meaningful. If Gilson and Schizer are correct, then each founder's stock is actually worth $\$ 5,000,000$, or something close to that amount. In that case, the founders should pay tax at ordinary income rates on $\$ 4,975,000-$ the difference between that $\$ 5,000,000$ value and the $\$ 25$,ooo they paid for the stock. This income would be taxed at the effective federal tax rate for compensation, which is currently $37.9 \% .3^{1}$ Thus, by pushing down the apparent value of the common stock, the thin common strategy saves Mark and Eduardo approximately $\$ 3.8$ million in current taxes.

While Mark and Eduardo pay less in current taxes, they increase their future tax liability. Absent the thin common strategy, Mark and Eduardo would receive a fair market value basis of $\$ 5,000,000$ in each of their stakes. This basis offsets the first $\$ 5,000,000$ of proceeds that each would receive from a sale of the stock, thereby exempting that amount from tax. By using the thin common strategy, Mark and Eduardo each receive a much lower basis of $\$ 25$, ooo in the stock-the amount they each paid..$^{2}$ Because the amount paid equals the claimed fair market value of the stock, receipt of the

not be entitled to a jury instruction that it is "part of the industry tradition to cheat on value"). Nonetheless, use of liquidation value in this setting is apparently commonplace. See Gilson \& Schizer, supra note 1 , at 892 . Perhaps planners are emboldened to do so given that the use of liquidation value has been sanctioned by regulatory guidance in the partnership arena. See Rev. Proc. 93-27, 1993-2 C.B. 343 (outlining safe harbor under which the IRS will not treat receipt of a profits interest in a partnership - that is, an interest that is not entitled to a liquidating distribution when it is issued-as a taxable event).

28. Technically, Mark and Eduardo would receive unvested shares, which means they would have to work for the company for a period of time before they become entitled to keep the shares. This vesting requirement would necessitate that Mark and Eduardo file $\S 8_{3}$ (b) elections to ensure the tax treatment described above.

29. See Gilson \& Schizer, supra note 1, at $88_{3}-8_{5}$.

3o. See id.

31. Some of the stock that Mark and Eduardo receive could be considered received in exchange for the business's pre-incorporation intangible property; in that case, some portion of the income could be tax-deferred. See I.R.C. $\$ 351$ (a).

32. See id. $\S 1012$ (providing for a basis equal to the cost of property). 
stock does not yield compensation income; hence, no further increases to the stock basis are warranted. Assuming the true fair market value of the stock is $\$ 5,000,000$, Mark and Eduardo each take the stock with a $\$ 4,975$,ooo built-in gain under this approach. This gain will be recognized if and when the stock is sold by the founder. Thus, while the thin common strategy reduces the founders' immediate tax liabilities, it also increases their future tax burden.

When viewed only from founders' perspectives, the thin common strategy is beneficial. Founders convert current ordinary compensation income (taxed immediately at $37.9 \%$ ) into deferred capital gain (taxed upon the sale of stock at $15 \%$ ). Previous commentary about the thin common strategy cites these benefits in arguing that founders' stock is taxadvantaged. ${ }^{33}$ As discussed below, we believe the existing literature has not devoted sufficient attention to the adverse consequences to the company in effectively compensating founders through the issuance of founders' stock. Yet prior to turning to our primary argument, we raise two other points concerning the conventional wisdom surrounding the thin common strategy.

1. The Thin Common Strategy as Normatively Acceptable Ex Post Tax Planning?

If Mark and Eduardo had consulted a tax advisor at the very beginning of their venture-before they began work and before they attracted the interests of any investors-the advisor could have instructed Mark and Eduardo to immediately form a new corporation. Each could have received half of the stock and paid a miniscule value for their stake without tax consequences because the company at that very early stage would actually have such little value. 34 Then, when a venture capitalist became interested in financing the company, it could have made its investment without resorting to the thin common strategy to preserve Mark's and Eduardo's character and deferral benefits. 35

One could therefore argue that whatever subsidy stems from the thin common strategy simply mitigates a penalty for getting late tax advice. If

33. See Fleischer, supra note 4 , at 64-65; Gilson \& Schizer, supra note 1, at 889-92.

34. See I.R.C. $\$ 8_{3}$ (a) (requiring gross income upon the receipt of property for services only to the extent the fair market value of the property exceeds the amount paid for the property). In this case, Mark and Eduardo are paying full fair market value for the stock.

35. In this case, a venture capitalist would typically require that founders subject their existing shares to certain vesting conditions. The insertion of these vesting conditions would have no tax consequences. See Rev. Rul. 07-49, 2007-2 C.B. 237. Alternatively, instead of buying stock in the existing company, a venture capitalist could form a new corporation and arrange for the existing corporation to be merged into the new corporation with the founders receiving unvested shares of the new corporation. Again, this would impose no adverse tax consequences on the founders, though they would need to file a $\$ 8_{3}$ (b) election to ensure the intended tax results. See id. 
Mark and Eduardo are too busy building the next Facebook or are too poor to obtain professional advice, the purported subsidy gives them a second bite at the apple, a result that may be defended on equitable grounds.

\section{Is Current Under-Enforcement a Subsidy?}

The thin common strategy obscures the value of founders' stock when it is received, thereby making it harder for the IRS to apply the law correctly. But if the law were applied correctly, the subsidy would be gone..$^{6}$ It is odd to call under-enforcement of existing law a subsidy, especially where it does not appear that the IRS has made a conscious administrative decision not to enforce the law to the fullest extent in this context. 37

Furthermore, while the venture capital community appears to take for granted that the IRS does not scrutinize the transaction, $3^{8}$ there is nothing preventing the IRS from doing so.39 Thus, whatever "subsidy" seems to exist may be ephemeral.

\section{B. AdJUSTABLE CONVERSION RATIOS AS HIDDEN BONUSES}

The thin common strategy is intended to convert founders' current ordinary income into future capital gain. Venture capitalists sometimes use another technique to achieve these results. When venture capitalists receive convertible preferred stock in return for their investment, the conversion ratio may be set to change upon the occurrence of specified events. $4^{\circ}$ For example, the conversion ratio could become more favorable to founders if the company hits a benchmark during a specified period (for example, a

$3^{6}$. See Johnson, supra note 10 , at 66 (emphasizing that the values asserted by founders are contrary to existing tax law and subject to criminal sanctions).

37. See Gilson \& Schizer, supra note 1, at 911 ("We doubt that the IRS intends to subsidize venture capital in this way."). In contrast, the IRS has announced the circumstances under which it will permit partnership profits interests to be issued to service providers without causing the recipient to recognize compensation income by reason of the grant. See Rev. Proc. 93-27, 1993-2 C.B. 343 .

38. See Gilson \& Schizer, supra note 1, at 892 ("[T]ax planners have commonly employed this aggressive strategy and, in the venture capital context, tax authorities have not routinely challenged it.").

39. See Johnson, supra note 10, at 67-68 (noting that the likelihood that the IRS will get around to challenging the valuation game is very low). On the other hand, litigation concerning issues of valuation may not be the most promising for the government given the costs of expert opinions and the absence of clear prospects for success. For instance, participants in the thin common strategy could respond to any attempt to increase the compensation income resulting from the issuance of common stock by contending that any "premium" value is properly allocable to contributed intangible property (for which nonrecognition treatment is available under $\S 35^{1}$ ).

40. See Myron S. Scholes et al., TaXes and Business Strategy: A Planning Approach 263 (4th ed. 2009) (noting that "the price at which the preferred stock can be converted into common stock is often made contingent on the performance of the company"). 
quadrupling of revenues within a year).41 The effect would be to reward founders with additional value-enhancing their shares' value by reducing the dilutive effect from the investor's exercise of its conversion rights-in the event of good performance. $4^{2}$ Venture capitalists could obtain the same result simply by issuing additional stock to the founders once the benchmark is reached or by paying cash equal to this value, but in those cases the founders would realize current ordinary income. By structuring the "bonus" as a conversion price adjustment, the effect is to increase the value of the founders' existing shares, which is not a taxable event.43 If and when the stock is sold, the increased value will be taxed at the lower capital gains rate. Thus, this strategy yields the same basic effects as the thin common strategy: a conversion of character from ordinary to capital and deferral of the tax.44

41. See id. ("If the company does well, say, in terms of accounting measures of performance, the conversion price to the venture capitalists increases.").

42. See id. (comparing the conversion rate adjustment to a bonus).

43. While adjustments to conversion ratios may sometimes be treated as taxable distributions to the benefitted shareholders, see I.R.C. $\$ 30_{5}$ (c) (2006), Treasury regulations exempt this scenario where the non-benefitted shareholders do not receive a related distribution of cash or property. See Treas. Reg. $\$ 1.305-7$ (a) (201 1 ).

44. To illustrate, consider a variation of the Mark and Eduardo example. Assume that they each purchase 250 shares of common stock for $\$ 25,000$. VC purchases convertible preferred stock for $\$ 5,000,000$ with a liquidation preference of the same amount. The preferred stock is convertible, at the election of VC, into $25^{\circ}$ shares of common stock. However, if the company hits certain accounting benchmarks, the preferred stock is convertible into 200 (rather than $25^{\circ}$ ) shares of common stock. Thus, if the benchmark is not hit, Mark and Eduardo will collectively own $66.7 \%$ (5oo shares out of $75^{\circ}$ outstanding shares) of the company post-conversion; if the benchmark is hit, Mark and Eduardo will own $71.4 \%(500 / 700)$ of the company. If the company is worth $\$ 50$,000,000 at the time the benchmark is hit, this $4.7 \%$ ownership shift results in an economic benefit of $\$ 2,35^{\circ}$,ooo to Mark and Eduardo. [4.7\% (the increase in percentage ownership by Mark and Eduardo) $\times \$ 50,000,000$ (the value of the company at the time of the adjustment $)=\$ 2,35^{\circ}$,ooo.] The company and the founders could obtain the same pre-tax economic results by simply conferring stock bonuses to Mark and Eduardo if the benchmark is hit. The amount of the stock bonus would be 125 shares to Mark and Eduardo collectively. Once the bonus is awarded, Mark and Eduardo will own 625 out of a total of 875 outstanding shares post-conversion. [5 oo shares (Mark and Eduardo's original stake) $+25^{\circ}$ (VC's stake) +125 (Mark and Eduardo's bonus shares) $=875$.] This is the same percentage $(71.4 \%)$ that they owned when the conversion ratio was adjusted in lieu of conferring bonus shares. The only difference between the two arrangements, other than their tax consequences, is that the absolute number of outstanding shares is different. But this is a trivial difference because the ownership percentages remain the same. Tax-wise, however, the arrangements yield vastly different results. When the conversion ratio adjusts, there are no immediate tax consequences to Mark and Eduardo because the bonus comes in the form of unrealized appreciation in the value of their shares. This unrealized appreciation will be recognized when the shares are sold and taxed at low capital gains rates. But if the stock bonus were conferred, Mark and Eduardo would realize ordinary income equal to the value of the shares they receive. Thus, the effect of adjustable conversion ratios is the same as that of the thin common strategy-a shift of ordinary income to capital gain and a deferral of tax liability. 


\section{C. "ACQHIRING"}

Facebook, Google, Zynga, and other similar companies recently have been acquiring startup companies simply to employ their founders and engineers.45 Shortly after the acquisitions, the acquirers jettison the target's projects while retaining the talent. Technology blogs call it being "acqhired." ${ }^{6}$ In a recent interview, Mark Zuckerberg described the practice in the following terms:

[A] lot of acquisitions that we make at Facebook are, you know, we look at great entrepreneurs out there who are building things. And often, the acquisitions aren't even to really buy their company or what they're doing. It's to get the really talented people who are out there trying to build something cool and say, you know, if you joined Facebook, you could work on this completely different problem. Isn't this a more important problem? And for the people who answer that question yes, they join. And that's how we've had the most success so far. 47

This technique for acquiring talent may seem odd. Why would companies acquire assets they don't want? The companies could instead simply lure the founders and engineers through lucrative employment arrangements. While it is common for key employees of startups to have noncompetition agreements that could make leaving costly, the acquirer could negotiate a payment to the startup in exchange for a waiver of the noncompete. This approach would allow Facebook to acquire the things it values (talented employees) while leaving behind the things it doesn't want (the projects in progress). Presumably, someone would place a higher value on the projects than Facebook, which simply discards them.

This puzzle might be explained by the fact that, without the founders and engineers, the projects themselves would not have much residual value. The founders and the engineers are the ones who best understand the projects and their strengths, weaknesses, and future prospects. In addition, by taking ownership of the project, Facebook can reduce the risk that the acqhired talent would still be working on the project on the side, as the fruits of that effort would inure to Facebook. Thus, taking ownership of the projects is a hedge of sorts against the risk of disloyalty.

However, these explanations do not appear fully persuasive. If a project is jettisoned by Facebook, the company presumably perceives the project as

45. Miguel Helft, For Buyers of Web Startups, Quest to Corral Young Talent, N.Y. TimES (May 18, 2011), http://www.nytimes.com/2011/05/18/technology/18talent.html.

46. Id.

47. Interview by Charlie Rose with Mark Zuckerberg, Founder, Facebook, and Sheryl Sandberg, COO, Facebook, in Palo Alto, Cal. (Nov. 7, 2011 ), available at http://venturebeat. com/2011/11/o7/zuckerberg-and-sandberg-on-charlie-rose/. 
valueless; $;^{8}$ surely, there often would be a party willing to pay some amount for these projects. As to the risk of disloyalty, that concern is pervasive to companies like Facebook. Talented high-tech employees always have a significant incentive, absent contractual provisions, to moonlight to the disadvantage of Facebook. This is true regardless of how the engineers initially came to work for the company. To mitigate the disloyalty risk, companies like Facebook rely on contractual provisions and other mechanisms, which should be sufficient in the acqhiring context even if they do not take ownership of the projects.

While the valuation and disloyalty justifications fail to fully explain why Facebook routinely buys projects it does not want, there may be a tax explanation for this seemingly odd behavior. By acquiring the entire startup company instead of just hiring the individual talent, Facebook allows founders and engineers to receive the familiar character conversion and deferral benefits. Facebook can structure the acquisition of startups as taxfree mergers, which allows the talent to roll-over their startup stock into Facebook stock without triggering any immediate income tax consequences.49 Their basis in the startup stock will carry over to the Facebook stock. $5^{\circ}$ They will recognize gain only when they liquidate the Facebook stock, and the gain will be taxable at capital gains rates.

If Facebook, instead, simply pays its own stock as signing bonuses, the founders and engineers will realize ordinary income at the time they receive the stock..$^{1}$ Thus, by buying the startup company, Facebook allows these individuals to convert immediate ordinary income to deferred capital gain..$^{2}$

48. On the other hand, perhaps the acquiring corporation recognizes that value of the project but, nonetheless, prefers to bury the project to eliminate threats to its business model.

49. See I.R.C. $\$ \S 354,368$ (a) (1) (A) (2006) (excluding gain realized on share exchanges via mergers). In order to qualify as a tax-free merger, the continuity-of-business-enterprise requirement must be satisfied. See Treas. Reg. $\$ 1.368-1$ (d) (2011). If Facebook jettisons the target's projects too quickly, it may run afoul of this condition.

5o. See I.R.C. $\$ 35^{8}$.

51. Technically, because the stock would typically be unvested, the employees would realize income at the time the stock vested. See id. $\S 8_{3}(\mathrm{a})$. Alternatively, if options were used, the employees would realize ordinary income at the time the options are exercised. See Treas. Reg. \$ $1.83-7$ (a).

52. Another tax advantage relates to the target's tax losses. By acquiring the target via a merger, Facebook inherits those losses, which it can use to absorb current or future income. Had Facebook merely acquired the talent, leaving the assets behind, it is likely that those losses would not be utilizable by the targets themselves or by other acquirers. See generally I.R.C. $\$ 3^{82}$ (limiting the ability of acquiring companies to utilize losses). The acquisition of losses seems unimportant to the acquirers, however. The acquiring companies appear to value companies based on the number of employees they are acquiring. See Helft, supra note 45 (noting that targets are valued on a "price per head" basis). Thus, the amount of losses the target has accumulated seems relatively unimportant in pricing the stock. 
By compensating these individuals in such a tax-friendly manner, Facebook surely reduces the amount of stock it must pay to acquire talent.53

\section{THE ISSUANCE OF FOUNDERS'STOCK GENERALLY}

The three techniques discussed above-the thin common strategy, the adjustable conversion ratios, and acqhiring -all convert immediate ordinary income into deferred capital gain. A similar conversion also occurs when founders' stock is simply issued to founders. Startups pay their founders almost entirely in stock, with minimal cash salaries. There are a number of nontax reasons to structure founders' compensation in this way. To take the most obvious example, equity compensation better aligns the founders' incentives with the interests of investors.54

In addition, the structure provides tax benefits to the founders in the form of conversion and deferral. Had the company paid founders higher cash salaries and less stock, the additional incremental cash salaries would be taxed at ordinary income rates when the cash is received. When the additional value is paid in the form of stock, any appreciation in the stock is deferred capital gain. When the founders work to enhance the value of the stock, the enhancement (unlike a cash payment) is not immediately taxed as ordinary income but instead will be taxed as capital gains only when the stock is sold.

For example, consider again the familiar Mark and Eduardo hypothetical. In the typical case, Mark and Eduardo will be paid low salaries. 55 The bulk of their pay is in their combined $66.7 \%$ equity stake in the company, which would typically vest ratably over four years. $5^{6}$ VC's stake is $33.3 \%$ (post-conversion), assuming that Mark and Eduardo ultimately vest in all of their shares. During Year 1, Mark and Eduardo work to "earn" onefourth of their stake, which puts their ownership stake at $33.3 \% .57$ At the

53. See Gregg D. Polsky \& Brant J. Hellwig, Taxing Structured Settlements, $5_{1}$ B.C. L. REv. 39 , 49-50 (2010) (explaining how the tax benefits from structured settlements can be shifted among the parties to the transaction); see also Eric D. Chason, Executive Compensation and Tax Neutrality: Taxing the Investment Component of Deferred Compensation, 31 CARDOzO L. REV. 1667, 1675 (noting that financially sophisticated parties will adjust their transactions in response to the formal incidence of any tax).

54. See Gilson \& Schizer, supra note 1, at 880-81 (noting the ubiquity of high-powered performance incentives designed to align incentives between managers and investors in the venture context).

55. See id. at 880 (noting that, in the venture context, the "potential for dramatic appreciation in the value of stock and options ... offsets low salaries").

56. See Yoichiro Taku, What Should the Vesting Terms of Founder Stock Be Before a Venture Financing?, MASHED REPORT (June 16, 2010, 3:49 PM), http://www.mashedreport.com/ 2010/o6/16/what-should-the-vesting-t_m_ooo34o.php (explaining that typical vesting is ratably over four years).

57. To illustrate, assume that Mark and Eduardo initially receive 100 shares collectively, which vest at a rate of 25 per year. $V C$ receives preferred stock convertible into 50 shares. At the end of year 1 , they are vested in 25 out of a total 75 outstanding and vested common shares ( $5^{\circ}$ 
end of Year 2, their stake is $50 \%$; Year $3,60 \%$; Year $4,66.7 \%$. Assuming that the business value grows $50 \%$ per year after VC's investment, the value of Mark's and Eduardo's combined stake is as follows:

Table 1: Summary of Developments

\begin{tabular}{|c|c|c|c|c|}
\hline $\begin{array}{c}\text { (A) } \\
\text { Event }\end{array}$ & $\begin{array}{c}\text { (B) } \\
\text { Enterprise } \\
\text { Value }\end{array}$ & $\begin{array}{c}\text { (C) } \\
\text { M \& E } \\
\text { Combined } \\
\text { Stake }\end{array}$ & $\begin{array}{c}\text { (D) } \\
\text { Year-end } \\
\text { Value of } \\
\text { M \&c E Stake }\end{array}$ & $\begin{array}{c}\text { (E) } \\
\text { Appreciation } \\
\text { in Value from } \\
\text { Prior Event }\end{array}$ \\
\hline $\begin{array}{c}\text { VC's } \\
\text { Investment }\end{array}$ & $\$ 15,000,000$ & $0 \%$ & $\$ 0$ & N/A \\
\hline End Year $\mathbf{I}$ & $\$ 22,500,000$ & $33 \cdot 3 \%$ & $\$ 7,5^{\circ 0,000}$ & $\$ 7,5^{\circ 0,000}$ \\
\hline End Year 2 & $\$ 33,75^{0,000}$ & $50 \%$ & $\$ 16,875$, ooo & $\$ 9,375,000$ \\
\hline End Year 3 & $\$_{5} 0,625,000$ & $60 \%$ & $\$ 30,375,000$ & $\$ 13,500,000$ \\
\hline End Year 4 & $\$ 75,937,5$ oo & $66.7 \%$ & $\$ 5^{0,625,000}$ & $\$ 20,25^{\circ}, 000$ \\
\hline
\end{tabular}

Column $\mathbf{E}$ shows the annual appreciation in the value of Mark's and Eduardo's stake. The increase in value is attributable to both the gradual earning of more shares (through vesting) and the growth in the value of the enterprise. Both types of appreciation are attributable, at least in part, to Mark's and Eduardo's personal efforts. They must remain employed for more shares to vest, and their work is a critical factor in the enterprise's appreciation. Had the economic value represented in Column $\mathrm{E}$ instead been delivered to Mark and Eduardo in the form of cash bonuses, they would have realized immediate ordinary income rather than deferred capital gains.

\section{Determining Whether a TAX AdVANTAge EXISTS}

\section{A. THE UNILATERAL PERSPECTIVE}

When viewed strictly from the founders' perspective, the strategies described in Part I appear to provide a significant tax benefit. However, in determining whether a true tax benefit exists, it is necessary to compare the tax results to the founders resulting from these structures with those resulting from a hypothetical analogous transaction-the receipt of stock

by VC and 25 by Mark and Eduardo). At the end of year 2 , they own $5^{\circ}$ out of 1 oo; year 3,75 out of 125 ; and year 4,100 out of $15^{\circ}$. 
options..$^{8}$ In theory, one could compare these strategies to cash payments rather than stock options, but we choose not to do so for two reasons. First, and most importantly, the issue we are addressing here is whether founders' stock is tax-advantaged. Stock options, as well as other types of equity compensation, are generally tax-advantaged,59 and their use is pervasive throughout the corporate world. In determining whether there is a tax advantage that is particular to founders' stock, the appropriate baseline must incorporate the general background tax-advantageousness of equity compensation. Prior commentators have used cash compensation as the comparison, ${ }^{60}$ but that unnecessarily conflates two issues: (1) whether equity compensation is generally advantaged, and (2) whether founders' stock is particularly advantaged. In this Article, we are interested in only the second issue. $^{61}$ To isolate the question of whether founders' stock is tax-advantaged, we use stock options as the comparison.

Second, significant nontax justifications support the use of equity compensation in the startup context, as previously mentioned. ${ }^{62}$ Stock options are, relative to cash compensation, a more realistic substitute for founders' stock. In fact, previous commentators who have determined founders' stock to be tax-advantaged have argued that founders' shares are economically identical to options. ${ }^{63}$

As mentioned above, founders who receive stock typically pay tax at capital gains rates when they liquidate the stock. The current maximum capital gains rate is $15 \% .{ }^{6}$ If the founders retain their stock until death,

$5^{8}$. Stock options come in two forms: incentive stock options ("ISOs") and nonqualified stock options ("NQSOs"). ISOs result in tax consequences very similar to those resulting from founders' stock: employees realize deferred capital gains and employers forfeit their compensation deductions. We compare the founders' stock to NQSOs, which provide much different tax results, as we explain. Therefore, all references to stock options below refer to NQSOs.

59. See generally Yale \& Polsky, supra note 7 , at $5^{8} 5^{-89}$ (explaining the general tax advantage of equity based compensation). For a further explanation of these tax advantages, see Knoll, The Tax Efficiency of Stock-Based Compensation, supra note 7; Walker, supra note 7.

6o. This is the comparison that both Gilson and Schizer, and Fleischer used.

61. For discussion of the first issue (whether equity compensation in general is taxadvantaged), see authorities cited supra note 59 .

62. See supra note 54 and accompanying text (discussing the nontax benefits of equity compensation in the venture context).

63. See Fleischer, supra note 4, at 74 ("In economic terms, each founder holds the equivalent of an at-the-money or out-of-the-money call option on one-third of the assets of the firm."); Gilson \& Schizer, supra note 1, at 898-99 (noting that the common stock that founders receive is "effectively a long-term option").

64. In recent years, there has been a small additional tax preference for the sale of "small business company" stock under $\S 1202$. Founders stock will usually qualify for this benefit. Currently, the first $\$ 10,000,000$ of gains is exempt from tax. This unusually generous exemption is scheduled to expire after 2011 and to return to a traditional $14 \%$ rate (rather than the general $15 \%$ rate on capital gains) on the first $\$ 10,000,000$ of gains. Given the 
their heirs can sell the stock without paying tax on any of the gain that accrued during the founders' lifetime. This means that the built-in gain at the founders' death is effectively tax exempt.

Suppose founders instead receive stock options with an exercise price equal to the amount paid for the founders' stock (for example, $\$ \mathbf{2 5}$, ooo in the Mark and Eduardo example). Upon liquidation of the options, ${ }^{65}$ the founders will realize compensation income equal to the excess of the proceeds received over the strike price of the option. ${ }^{66}$ If they die while continuing to own the options, their heirs will owe ordinary income tax on the proceeds when they liquidate the options. ${ }^{67}$ The maximum ordinary income tax rate is $35 \%$, and because income realized upon exercise of an option is treated as compensation, it is also subject to employment tax at a $2.9 \%$ effective rate. This yields a combined effective tax rate of $37.9 \% .^{68}$ These tax rates applicable to founders' stock and stock options are summarized in the following table.

relatively small preference that the traditional rule provides, and the $\$ 10,000,000$ cap, we ignore the $\$ 1202$ preference.

65. Founders would liquidate their stock options by first exercising the option and then selling the underlying stock. These steps typically occur in quick succession. Exercising the option and holding on to the underlying stock for a significant period of time is an uncommon strategy. This is consistent with the fact that delayed exercise is tax-advantaged relative to early exercise-and-hold. See SCHOLES ET AL., supra note 40 , at $25^{6}$ (explaining that early exercise "is not tax favored"). The only time it would make sense to exercise-and-hold would be if the option period were expiring; the stock options we hypothesize would have an unlimited option period to synchronize with founders' stock, which can be held forever.

66. If founders received stock options in lieu of founders' stock, as we are hypothesizing, a minimal amount of stock would have to be issued to the founders to give them the requisite voting powers they usually have. Thus, founders could be issued, in addition to stock options, shares of a special class of common stock that have significant voting power but minimal distribution/liquidation rights. By pairing these high-vote/low-value shares with stock options, the arrangement would have the same non-tax economic effects as the founders' stock structure. Because the high-vote shares would have minimal value, we ignore them in our analysis.

67. The proceeds of the options above the strike price would constitute income in respect of a decedent under $\S 691$ (a), which is not entitled to a basis step-up at death. See I.R.C. $\S$ 1014 (c) (2006).

68. Technically, $1.45 \%$ of the employment tax is owed by the employer. However, because the incidence of employment taxes is typically borne by the employee, we treat the employee as owing all of the employment taxes. In the case of stock option grants, employees are often required to pay the employer's share of employment taxes, thus directly accomplishing the shift in the incidence of the employer's share. As explained supra note 20, we use the full $2.9 \%$ statutory rate of the combined Medicare tax (even though the employer's portion of the Medicare tax is deductible, which gives rise to a lower effective rate based on the value of the employer's deduction) to avoid understating the benefit of using founders' stock to compensate executives. 
Table 2: Tax Effects to the Founders

\begin{tabular}{|c|c|c|c|}
\hline $\begin{array}{c}\text { Type of Equity } \\
\text { Issued }\end{array}$ & $\begin{array}{c}\text { Tax Rate at } \\
\text { Issuance/ } \\
\text { Vesting }\end{array}$ & $\begin{array}{c}\text { Tax Rate if } \\
\text { Liquidated During } \\
\text { Founder's Life }\end{array}$ & $\begin{array}{c}\text { Tax Rate if } \\
\text { Liquidated After } \\
\text { Founder's Death }\end{array}$ \\
\hline $\begin{array}{c}\text { Founder's Stock } \\
\text { ("FS") }\end{array}$ & No Tax & $15 \%$ & o\% \\
\hline Stock Options & No Tax & $37.9 \%$ & $37.9 \%$ \\
\hline $\begin{array}{c}\text { Tax-Rate } \\
\text { Advantage for } \\
\text { FS }\end{array}$ & None & $\mathbf{2 2 . 9 \%}$ & $37.9 \%$ \\
\hline
\end{tabular}

Thus, viewed from the perspective of the founders only, founders' stock is tax-advantaged relative to analogous stock options, regardless of when the equity interests are liquidated. The tax-rate reductions are $22.9 \%$ for lifetime sales and $37.9 \%$ for postmortem sales. The liquidations of founders' stock and stock options would occur at the same time, when the founders make the decision to liquidate part or all of their equity interest. ${ }^{69}$ As a result, there is no need to make any time-value-of-money adjustments to compare the tax consequences.

\section{B. A PREVIEW OF THE MULTILATERAL PERSPECTIVE}

While a unilateral perspective suggests a clear tax benefit for founders when they receive founders' stock rather than stock options, the analysis cannot end there. If a particular structure grants a tax benefit to one side of a transaction but also imposes an equal burden on the other party, the structure is not tax-advantaged. Further, the distributional results of the transaction should be unaffected by the new structure, as the parties would typically adjust their pricing to reflect the changes of their respective tax burdens. $7^{\circ}$

Thus, analysts considering whether founders' stock is advantaged must consider the effect on the company if stock options were substituted for founders' stock. When the company issues founders' stock, it receives no deductions-not when the stock is issued, not when it vests, and not when it is liquidated by the founders (or their heirs).71 Alternatively, if stock options

69. See Johnson, supra note 10 , at 69 (using the same assumption that liquidations of founders' stock and stock options would occur at the same time).

7o. See GRUBER, supra note 7 , at 528 ("The side of the market on which the tax is imposed is irrelevant to the distribution of tax burdens.").

71. See Johnson, supra note 10, at 68 (noting that by using founders' stock, the company "give[s] up its compensation deduction"). This conclusion assumes that the unrestricted value of the founders' stock is respected as equal to the property contribution of the founders and 
are issued in lieu of stock, the company receives a deduction when the options are liquidated equal to the proceeds of such liquidation (less the strike price of the option), which is the same amount of income on which the founder is taxed..$^{2}$ These results are summarized in the following table.

Table 3: Tax Effects to the Company

\begin{tabular}{|c|c|c|c|}
\hline $\begin{array}{c}\text { Type of Equity } \\
\text { Issued }\end{array}$ & $\begin{array}{c}\text { Tax Effect on } \\
\text { Company } \\
\text { upon } \\
\text { Issuance }\end{array}$ & $\begin{array}{c}\text { Tax Effect on } \\
\text { Company } \\
\text { upon Vesting }\end{array}$ & $\begin{array}{c}\text { Tax Effect on } \\
\text { Company upon } \\
\text { Liquidation }\end{array}$ \\
\hline Founders' stock & No tax effect & No tax effect & No tax effect \\
\hline Stock options & No tax effect & No tax effect & $\begin{array}{c}\text { Tax deduction equal } \\
\text { to amount of } \\
\text { proceeds }\end{array}$ \\
\hline
\end{tabular}

Thus, when viewed solely from the company's perspective, issuing stock options is more tax efficient than issuing founders' stock. In the case of stock options, the company will receive a deduction for compensation paid, which can be quite valuable.73 However, the company will receive no compensation deductions if it uses the founders' stock structure. 74

Taking a proper multilateral perspective, the issue of whether founders' stock is tax-advantaged depends on whether the tax benefit to the founders from character conversion exceeds the tax burden to the company from losing its deductions. If so, using founders' stock is tax-advantaged; otherwise, it is not.

\section{COMPARING FOUNDERS'STOCK TO CARRIED INTERESTS}

A number of commentators have argued that the tax benefit from founders' stock is similar to the tax benefit received by investment fund managers in their arrangements with their own investors.75 Managers of

that any future compensatory element of the transfer is foreclosed through a timely $\S 83$ (b) election.

72. See Treas. Reg. $\$ 1.8$ 3-7 (b) (3) (granting employer a deduction at exercise of the stock option equal to the spread between fair market value of the stock and exercise price of the option).

73. See Johnson, supra note 10 , at 68 (explaining that the lost deduction from founders' stock is "ordinarily more valuable than achieving employee capital gain").

74. See id. (noting the forfeiture of compensation deductions).

75. See Fleischer, supra note 4, at 62 n.4; Kristof, supra note 5; Testimony of Jack S. Levin to the House Ways \& Means Comm. (Sept. 6, 2007), http://www.kirkland.com/files/Levin_ Testimony_ogo6o7.pdf, at 3 (analogizing the carried interest tax benefit to the tax benefit received by Bill Gates when he sells Microsoft stock). 
private equity funds (both venture and buyout) receive an incentive pay component, known as a carried interest, which typically entitles them to $20 \%$ of the fund's overall profits. $7^{6}$ When fund managers receive their "carry," they recognize capital gains, even though the carry is clearly received in consideration for their services. 77 This provides a tax benefit to the managers. Had they received cash in lieu of carried interest (for example, pursuant to a promise to pay cash equal to $20 \%$ of the fund's profits), the managers would realize ordinary income..$^{8}$ Viewed strictly from the fund managers' perspective, this character conversion is just like the benefit to founders.

However, the analysis cannot end there. The consequences to the fund managers' counterparties must be taken into account.79 Because private equity funds are structured as tax partnerships, rather than corporations, the fund's investors are the counterparties to the fund managers. When fund managers convert ordinary income to capital gain by structuring their incentive pay as carry, they also effectively convert the fund's investors' deductions from ordinary deductions to capital losses. ${ }^{80}$ This conversion generally proves disadvantageous because ordinary deductions are more valuable. To determine whether carried interest is tax-advantaged, we therefore must compare this burden to the benefit received by fund managers. ${ }^{81}$ Because of the unique nature of private equity funds, this comparison is fairly easy.

Approximately half of private equity fund investment is made by parties that do not pay U.S. taxes, such as pension funds, endowments, charitable foundations, and foreign persons and entities. ${ }^{82}$ Accordingly, these investors are indifferent as to the adverse character conversion resulting from structuring managerial incentive pay as carried interest as opposed to cash..$^{83}$ The other significant source of investment funds are banks, insurance

76. See generally Fleischer, supra note 3 .

77. See id. at 3; see also Dagres v. Comm'r, 136 T.C. 263, 286-87 (2011) (characterizing a profits interest held by an LLC that served as the general partner of an investment fund as "compensation for personal services" notwithstanding the pass-through character of capital gain income typically attributable to such interest).

78. See Fleischer, supra note 3, at 3 .

79. See authorities cited in supra note 7 (describing the joint tax perspective).

8o. See Sanchirico, supra note 3 , at $109^{2}$ (describing the effect on investors from carried interest).

81. See id.; see also Gregg D. Polsky, Private Equity Management Fee Conversions, 122 TAX NOTES 743, 746-47 (2009) (making this comparison).

82. See Robert J. Shapiro \& Nam D. Pham, The Role of Private Equity in U.S. CAPITAL MARKETS 11 (2008) (showing that nearly half of private equity investments in buyout and mezzanine funds were by pensions, charitable organizations, or foreign taxpayers).

83. See Sanchirico, supra note 3, at $\log _{2}$ (noting the tax-indifference of these investors). 
companies, and U.S. corporations, ${ }^{84}$ who are all generally unaffected by the adverse character swap. ${ }^{85}$ Accordingly, it is easy to conclude that carried interest is globally tax-advantaged because fund managers receive a benefit and the vast majority of investors bear no corresponding burden.

In the case of founders' stock, the counterparty is the startup company, typically a U.S. corporation. While it is true that most startups do not pay taxes in early stages because they lose money during this period, the companies hope to eventually become profitable. At that point, they will face tax liabilities. Thus, the founders' counterparty may be significantly burdened by the deduction forfeiture associated with the use of founders' stock. ${ }^{86}$ This important fact distinguishes the founders' stock scenario from the carried interest issue arising in the partnership context.

\section{Determining the Global Tax Advantage or Disadvantage}

To determine whether the use of founders' stock is globally taxadvantaged, and to calculate the amount of any such advantage, certain assumptions must be made about future events. Consider, for instance, statutory tax rates. If the capital gains rates increase, founders' stock is less advantageous for founders, but the company's tax treatment is unaffected. Therefore, a capital gains rate hike would make founders' stock less advantageous (or more disadvantageous) overall than before. Changes to the compensation tax rates and the corporate tax rates will similarly affect the analysis, as summarized in the table below.

84. See SHAPIRO \& PHAM, supra note 82, at 11 (showing that approximately one-quarter of private equity investments were made by banks, insurance companies, and other corporations from 2000 through 2007 ).

85. See Knoll, Carried Interests, supra note 7, at 130 (noting the cost of character conversion from carried interest structure to corporations is insignificant). U.S. individuals contribute about $20 \%$ of dollars invested in private equity (either directly or through intermediary funds). See SHAPIRO \& PHAM, supra note 82, at 11 (showing that about twenty percent of investments from 2000 through 2007 were by family/individuals or intermediaries). These individuals, while theoretically adversely affected by character conversion, do not suffer very much because the ordinary deductions that they would get in lieu of paying carried interest are substantially impaired by $\$ 212$ of the Code. See Polsky, supra note 81 , at 747 .

86. To be clear, in the carried interest context, a U.S. corporate investor in a private equity fund is generally not adversely affected by the character swap when their ordinary deductions are converted into capital losses. In the founders' stock situation, the startup company (a U.S. corporation) effectively converts ordinary deductions into thin air, which is a potentially significant adverse consequence as discussed in Part III. 
Table 4: Effect of Tax Rate Changes

\begin{tabular}{|c|c|c|c|}
\hline & $\begin{array}{c}\text { Capital Gains } \\
\text { Tax Rate } \\
\text { Changes }\end{array}$ & $\begin{array}{c}\text { Compensation } \\
\text { Tax Rate } \\
\text { Changes }\end{array}$ & $\begin{array}{l}\text { Corporate Tax } \\
\text { Rate Changes }\end{array}$ \\
\hline $\begin{array}{c}\text { Effect on } \\
\text { Founders Who } \\
\text { Receive } \\
\text { Founders' Stock } \\
\text { in Lieu of Stock } \\
\text { Options }\end{array}$ & $\begin{array}{c}\text { Increase: less } \\
\text { advantageous } \\
\text { Decrease: } \\
\text { more } \\
\text { advantageous }\end{array}$ & $\begin{array}{l}\text { Increase: more } \\
\text { advantageous } \\
\text { Decrease: less } \\
\text { advantageous }\end{array}$ & No effect \\
\hline $\begin{array}{c}\text { Effect on } \\
\text { Companies Who } \\
\text { Issue Founders' } \\
\text { Stock in Lieu of } \\
\text { Stock Options }\end{array}$ & No effect & No effect & $\begin{array}{l}\text { Increase: more } \\
\text { disadvantageous } \\
\text { Decrease: less } \\
\text { disadvantageous }\end{array}$ \\
\hline
\end{tabular}

Predicting future tax rates is nearly impossible, as the government's need for additional revenues, the amount of economic growth, and the political environment are difficult to foresee, particularly for periods many years in the future. ${ }^{87}$ Even if one generally believes that tax rates must rise given current budgetary projections, it would still be unclear how that belief would affect the perceived tax advantage of founders' stock. Will all three tax rates (capital gains, compensation, and corporate) increase, or will only one or two? If more than one rate increases, will they increase by the same number of percentage points? If all three tax rates increase by the same number of percentage points, the amount of global advantage or disadvantage resulting from the founders' tax strategies would remain constant. If, on the other hand, the capital gains rate and the compensation tax rate increase by the same number of percentage points, but the corporate tax rate increases by more, then whatever global advantage exists for founders' stock would decrease (or whatever disadvantage would increase). Because of the uncertainty as to how these three tax rates will move overall and in relation to one another, we make the common assumption that current statutory rates will remain in effect. ${ }^{88}$

In addition to future tax rates, other factors significantly affect the analysis. One critical factor is whether and when a company becomes profitable. At that point, the company could begin to use the deductions

87. See Yale \& Polsky, supra note 7, at 634 (noting that predicting future statutory rates is speculative).

88. See, e.g., Oddi v. Ayco Corp., 947 F.2d 257, 261-62 (7th Cir. 1991) (applying, in the litigation context, a presumption that current tax rates will remain constant). 
that would be available if stock options were issued in lieu of founders' stock. The earlier this utilization occurs, the greater the detriment to companies that forfeit compensation deductions through the issuance of founders' stock. ${ }^{89}$ This is because the time value of money reduces the benefit of the tax deductions stemming from stock options as the deductions remain unutilized.90 If the deductions end up never being utilized (for example, because the company never reaches the point of overall profitability ${ }^{11}$ ), the issuance of founders' stock and stock options would have the same effect on companies. The forfeiture of a deduction that is forever worthless to the company does not impose a detriment; hence, there would be no tax disadvantage to the company from issuing founders' stock. Another significant factor is whether any of the founders' stock is liquidated after the death of the founders. When founders' stock is retained until death, the appreciation in the stock in the founders' hands is exempted from taxation due to the operation of the stepped-up basis rule of $\S 1014$. Thus, the more stock that is retained until death, the greater the tax advantage enjoyed by the founders.

To illustrate the interaction of these two factors-loss utilization rate and retention of equity interests until death-we analyze several hypothetical scenarios below to determine whether the use of founders' stock produces an overall tax advantage $.9^{2}$ These scenarios are highly stylized to keep the calculations somewhat simple. Even so, they illustrate the manner in which the overall tax benefit of founders' stock should be determined. All scenarios begin with a founder receiving $\$ 5$,ooo, ooo worth of founders' stock for $\$ 25$,ooo or, alternatively, a stock option to purchase the same amount of stock for $\$ 25,000.93$

89. Assuming the employee recognized capital gain income and the employer recognized its deduction in the current year, Johnson determined that the use of founders' stock (that is, favoring employee capital gain) will prove beneficial to the parties on the whole only if the value of the employer's deduction falls below $23.5 \%$. See Johnson, supra note 10 , at 69 n.97. Under our analysis, we assume that the employer's deduction may be valueless at the time it is first available, but we consider the present value of that deduction to the employer based on assumptions as to when the employer will achieve profitability (at which point it can use the carried-over deduction).

9o. See Michael Cooper \& Matthew Knittel, Partial Loss Refundability: How Are Corporate Tax Losses Used?, 59 NAT'L TAX J. $65^{1}, 65^{1}$ (2006) (explaining that loss carryforwards are effectively only partially refundable "because the real value of the loss erodes over time").

91. There are other reasons for non-utilization, as discussed below.

92. We do not attempt to determine which of these scenarios is more likely to occur; rather, we employ these scenarios to illustrate the combined tax consequences to the parties based on varying levels of success achieved by the venture.

93. Before $\S 409 \mathrm{~A}$ became effective in 2005 , there were no tax concerns with issuing a stock option that was arguably in-the-money at the time of grant. I.R.C. $\S 4$ ogA (2006). (We say "arguably" because the thin common strategy could support the view that the underlying stock is only worth $\$ 25$,ooo.) After $\$ 409 \mathrm{~A}$ became effective, the tax risk of granting potentially inthe-money options grew significantly. Section $409 \mathrm{~A}$ is of relatively recent vintage and the pervasive industry use of founders' stock and the argument that founders' stock is tax- 


\section{A. THE SUCCESSFUL CASES}

1. Home Run

In this case, we assume that the company's stock price increases by a factor of $5^{\circ}$ during the first five years. At the end of the five-year period, company stock is sold at an initial public offering ("IPO"). In the next five years, the company's stock price doubles. During Year 10, the company hits the point of overall profitability, enabling it to utilize all of its current and previous tax deductions. Over the next thirty years, the company's stock price increases sevenfold. The founder disposes of the stock or options as follows: one-third at the IPO five years out, one-third at ten years out, and one-third immediately after death at the end of Year $4^{\circ}$. These facts are summarized below.

Table 5: Home Run Fact Summary

\begin{tabular}{|c|c|c|c|c|}
\hline $\begin{array}{c}\text { Time } \\
\text { from } \\
\text { Issuance }\end{array}$ & Event & $\begin{array}{c}\text { Stock Value } \\
\text { Relative to } \\
\text { Previous Event } \\
\text { (Annual IRR) }\end{array}$ & $\begin{array}{c}\text { Company } \\
\text { Attained } \\
\text { Profitability? }\end{array}$ & $\begin{array}{c}\text { Stock } \\
\text { Disposition } \\
\text { by Founder? }\end{array}$ \\
\hline 0 & Issuance & N/A & No & No \\
\hline 5 & IPO & 5 ox $(119 \%)$ & No & $\begin{array}{c}1 / 3 \text { of } \\
\text { original } \\
\text { stake }\end{array}$ \\
\hline 10 & $\begin{array}{c}\text { Point of } \\
\text { Profitability }\end{array}$ & $2 \times(15 \%)$ & Yes & $\begin{array}{c}1 / 3 \text { of } \\
\text { original } \\
\text { stake }\end{array}$ \\
\hline 40 & Death & $7 \times(6.7 \%)$ & Yes & $\begin{array}{c}1 / 3 \text { of } \\
\text { original } \\
\text { stake }\end{array}$ \\
\hline
\end{tabular}

In this case, the tax benefit to the founder in using founders' stock (rather than stock options) is approximately $\$ 78.5$ million (expressed in Year o dollars), while the corresponding tax detriment to the company is approximately $\$ 88.5$ million.94 Calculations for this hypothetical and the

advantaged both predated its enactment. Furthermore, $\S 4$ ogA has been roundly criticized on policy grounds, making its staying power uncertain. In particular, $\S 4$ ogA's harsh treatment of in-the-money options has been criticized as lacking any good justification. See David I. Walker, The Non-Option: Understanding the Dearth of Discounted Employee Stock Options, 89 B.U. L. REV. 1505,1520 (2009).

94. See infra Appendix, Part I. 
ones that follow are provided in the Appendix. Under these facts, therefore, there is a distinct tax disadvantage-about $\$ 10$ million-to using founders' stock in lieu of stock options.

\section{Triple}

In this case, we assume that the company's stock price increases by a factor of 25 during the first five years. At the end of the five-year period, the company undergoes an IPO. In the next eight years, the company's stock price doubles. During Year 13, the company reaches the point of overall profitability. Over the next twenty-seven years, the company's stock price increases by a factor of six. The founder disposes of the stock or options as follows: one-third at the IPO five years out, one-third at the end of Year 13, and one-third immediately after death at the end of Year $4^{\circ}$.

Table 6: Triple Fact Summary

\begin{tabular}{|c|c|c|c|c|}
\hline $\begin{array}{c}\text { Time } \\
\text { from } \\
\text { Issuance }\end{array}$ & Event & $\begin{array}{c}\text { Stock Value } \\
\text { Relative to } \\
\text { Previous Event } \\
\text { (Annual IRR) }\end{array}$ & $\begin{array}{c}\text { Company } \\
\text { Attained } \\
\text { Profitability? }\end{array}$ & $\begin{array}{c}\text { Stock } \\
\text { Disposition } \\
\text { by Founder? }\end{array}$ \\
\hline 0 & Issuance & N/A & No & No \\
\hline 5 & IPO & $25 \times(90 \%)$ & No & $\begin{array}{c}1 / 3 \text { of } \\
\text { original } \\
\text { stake }\end{array}$ \\
\hline 13 & $\begin{array}{c}\text { Point of } \\
\text { Profitability }\end{array}$ & $2 \times(9 \%)$ & Yes & $\begin{array}{c}1 / 3 \text { of } \\
\text { original } \\
\text { stake }\end{array}$ \\
\hline 40 & Death & $6 \times(6.9 \%)$ & Yes & $\begin{array}{c}\text { original } \\
\text { stake }\end{array}$ \\
\hline
\end{tabular}

The tax benefit to the founder of using founders' stock is roughly $\$ 34.5$ million, while the associated tax burden to the company is $\$ 37.5$ million.95 The net result is a $\$ 3$ million overall tax disadvantage from using founders' stock in lieu of stock options.

\section{Double}

Here we assume that the company's stock price grows twenty times during the first six years. At the end of the six-year period, the IPO occurs.

95. See infra Appendix, Part II. 
In the next fourteen years, the company's stock price doubles. At the end of those fourteen years, the company hits the point of overall profitability. Over the next twenty years, the company's stock price quadruples. The founder disposes of the stock or options as follows: one-third at the IPO six years out, one-third at Year 2o, and one-third immediately after death at the end of Year 40, as shown below.

Table 7: Double Fact Summary

\begin{tabular}{|c|c|c|c|c|}
\hline $\begin{array}{c}\text { Time } \\
\text { from } \\
\text { Issuance }\end{array}$ & Event & $\begin{array}{c}\text { Stock Value } \\
\text { Relative to } \\
\text { Previous Event } \\
\text { (Annual IRR) }\end{array}$ & $\begin{array}{c}\text { Company } \\
\text { Attained } \\
\text { Profitability? }\end{array}$ & $\begin{array}{c}\text { Stock } \\
\text { Disposition } \\
\text { by Founder? }\end{array}$ \\
\hline 0 & Issuance & N/A & No & No \\
\hline 6 & IPO & $20 \times(65 \%)$ & No & $\begin{array}{c}1 / 3 \text { of } \\
\text { original } \\
\text { stake }\end{array}$ \\
\hline 20 & $\begin{array}{c}\text { Point of } \\
\text { Profitability }\end{array}$ & $2 \times(5.1 \%)$ & Yes & $\begin{array}{c}1 / 3 \text { of } \\
\text { original } \\
\text { stake }\end{array}$ \\
\hline 40 & Death & $4 \times(7.2 \%)$ & Yes & $\begin{array}{c}1 / 3 \text { of } \\
\text { original } \\
\text { stake }\end{array}$ \\
\hline
\end{tabular}

The founder's tax benefit is approximately $\$ 20$ million, which roughly equals the corresponding tax burden borne by the company. $9^{6}$ Thus, this case is effectively a dead heat, where neither a significant tax advantage nor disadvantage results from the use of founders' stock. The most important distinction between this hypothetical and the two previous ones is the delay in profitability, which delayed the company's utilization of the Year 6 deductions resulting from the exercise of stock options. This delay made those Year 6 deductions less valuable in present-value terms, thereby reducing the resulting tax benefit to the company from use of stock options to compensate the founders.

\section{Single}

In this case, we assume that the company's stock price triples in the first ten years, after which the company undergoes an IPO. Over the next twenty years, the company's stock price triples again. At the end of those twenty

96. See infra Appendix, Part III. 
years, the company finally hits the point of overall profitability. Over the next ten years, the stock price doubles. The founder again disposes of onethird of the stock or options at IPO, one-third at the point of overall profitability (in Year $3^{\circ}$ ), and one-third after death.

Table 8: Single Fact Summary

\begin{tabular}{|c|c|c|c|c|}
\hline $\begin{array}{c}\text { Time } \\
\text { from } \\
\text { Issuance }\end{array}$ & Event & $\begin{array}{c}\text { Stock Value } \\
\text { Relative to } \\
\text { Previous Event } \\
\text { (Annual IRR) }\end{array}$ & $\begin{array}{c}\text { Company } \\
\text { Attained } \\
\text { Profitability? }\end{array}$ & $\begin{array}{c}\text { Stock } \\
\text { Disposition } \\
\text { by Founder? }\end{array}$ \\
\hline 0 & Issuance & N/A & No & No \\
\hline 10 & IPO & $3 \times(11.6 \%)$ & No & $\begin{array}{c}1 / 3 \text { of } \\
\text { original } \\
\text { stake }\end{array}$ \\
\hline 30 & $\begin{array}{c}\text { Point of } \\
\text { Profitability }\end{array}$ & $3 \times(5.7 \%)$ & Yes & $\begin{array}{c}1 / 3 \text { of } \\
\text { original } \\
\text { stake }\end{array}$ \\
\hline 40 & Death & $2 \times(7.2 \%)$ & Yes & $\begin{array}{c}1 / 3 \text { of } \\
\text { original } \\
\text { stake }\end{array}$ \\
\hline
\end{tabular}

The benefit to the founders under this scenario is $\$ 2.34$ million, and the detriment to the company is $\$ 2.24$ million, yielding a net tax advantage of only $\$ 100,000.97$ Thus, under these facts, the use of founders' stock is taxadvantaged on the whole, although the extent of the tax advantage is relatively small.

\section{Summary}

'Several conclusions may be drawn from the foregoing examples. First, in the most successful ventures, founders' stock will tend to be heavily disadvantaged relative to stock options on an overall basis. This is because extremely successful companies will be able to utilize deductions stemming from the stock options either immediately upon the founder's exercise or without much delay. Second, moving from the most successful ventures to only marginally successful ones, the net tax advantage of stock options tends to shrink, eventually becoming advantageous on the whole. But, importantly, the net tax advantage of founders' stock in the marginally successful cases is inherently self-limiting. In those cases, the tax advantage

97. See infra Appendix, Part IV. 
to founders is necessarily small because marginal successes will, by definition, not generate the large appreciation in the stock price needed to create significant amounts of unilateral tax gains for founders.

\section{B. THE UNSUCCESSFUL CASES}

\section{False Start}

In one context, founders' stock can yield a significant overall tax advantage. Some companies will never be able to use the deductions that would be generated if stock options were issued in lieu of founders' stock. This is because they either (1) liquidate before reaching the point of overall profitability, effectively forfeiting their deductions, $9^{8}$ (2) do not achieve profitability before the net operating losses resulting from the deductions expire, 99 or (3) are subject to an ownership change while the company has a very low valuation, which would significantly impair the company's ability to make use of the net operating losses. ${ }^{100}$ In all three of these instances, the company will be considered a significant disappointment in the end. Nevertheless, it is possible that the company's stock was highly regarded at certain junctures, based on erroneous predictions about its future profitability. In these "false start" cases, founders could realize significant benefits from using founders' stock, yet the company does not suffer any significant corresponding detriment because the foregone deductions would never be monetized in the form of reduced tax payments.

For instance, consider the following hypothetical, using the same basic facts as before. The value of the founder's equity interest increases forty times between issuance and IPO in Year 6, based on the expectation of significant future profits. Despite that expectation, the profits never materialize and the company fails in Year 12. The founder sells one-third of the stock or options at IPO and another third in Year 9, when the stock price remains forty times the original value. The founder's remaining onethird stake becomes worthless when the company liquidates in Year 12.

98. See Johnson, supra note 10 , at $3^{1-32}$ (explaining that unused losses of failed companies disappear).

99. Net operating losses expire twenty years after they are created. See I.R.C. $\S 172(\mathrm{~b})(1)$ (A) (ii) (2006). Thus, if losses recognized in Year 6 are not used before the end of Year 26 , they will expire.

10o. See id. $\$ 382(\mathrm{a})$, (b) (subjecting pre-ownership change net operating losses ("NOLs") to an annual limit equal to the product of the corporation's value at the time of the ownership change and the long-term tax-exempt rate in effect at the time of the ownership change). The long-term tax-exempt rate for ownership changes occurring in July 2011 was $4.30 \%$. See Rev. Rul. 2011-14, 2011-27 I.R.B. 31. Thus, for example, if a company had a value of $\$ 5^{\circ}$ million at the time of an ownership changes, the maximum amount of NOLs it could use in any postownership-change year would be $\$ 2,15^{\circ}$,ooo. 
Table 9: False Start Fact Summary

\begin{tabular}{|c|c|c|c|c|}
\hline $\begin{array}{c}\text { Time } \\
\text { from } \\
\text { Issuance }\end{array}$ & Event & $\begin{array}{c}\text { Stock Value } \\
\text { Relative to } \\
\text { Previous Event } \\
\text { (Annual IRR) }\end{array}$ & $\begin{array}{c}\text { Company } \\
\text { Attained } \\
\text { Profitability? }\end{array}$ & $\begin{array}{c}\text { Stock } \\
\text { disposition } \\
\text { by } \\
\text { Founder? }\end{array}$ \\
\hline 0 & Issuance & N/A & No & No \\
\hline 6 & IPO & $40 \times(85 \%)$ & No & $\begin{array}{c}1 / 3 \text { of } \\
\text { original } \\
\text { stake }\end{array}$ \\
\hline 9 & Stock sale & $1 \times(0 \%)$ & No & $\begin{array}{c}1 / 3 \text { of } \\
\text { original } \\
\text { stake }\end{array}$ \\
\hline 12 & Worthlessness & ox (N/A) & No & $\begin{array}{c}1 / 3 \text { of } \\
\text { original } \\
\text { stake (for } \\
\text { zero) }\end{array}$ \\
\hline
\end{tabular}

In this case, the founder realizes a tax benefit from using founders' stock of nearly \$20 million. ${ }^{101}$ The company, however, suffers no detriment whatsoever because the foregone deductions from using founders' stock became useless. ${ }^{102}$ Accordingly, on the whole, this hypothetical yields a significant tax advantage to the parties.

\section{Strikeout}

Finally, there is the far more common case, where a startup fails before an IPO or successful takeover. In these cases, using founders' stock or stock options yields the same tax results. In both cases, the founders' equity interests are never successfully liquidated; thus, the founders walk away with little to nothing. The company never receives deductions, either because (1) the founders received stock, thereby forfeiting any deductions, or (2) the founders' options are not exercised, thereby precluding any deduction. ${ }^{10}$ Thus, in the strikeout case, there is neither an advantage nor disadvantage in using founders' stock.

101. See infra Appendix, Part V.

102. See infra Appendix, Part V.

103. See Treas. Reg. $\$ 1.83-7$ (2011) (providing employer with deduction upon exercise of stock options). 
C. SUMMARY

These results are summarized in the following table, with the most important conclusions highlighted:

Table 10: Summary of Results

\begin{tabular}{|c|c|c|}
\hline Scenario & $\begin{array}{c}\text { Net Advantage or Disadvantage in } \\
\text { Using Founders' Stock }\end{array}$ & $\begin{array}{c}\text { Size of the } \\
\text { Advantage or } \\
\text { Disadvantage }\end{array}$ \\
\hline Home Run & Disadvantage & Large \\
\hline Triple & Disadvantage & Small \\
\hline Double & Neutral & N/A \\
\hline Single & Advantage & Very small \\
\hline False Start & Advantage & Large \\
\hline Strikeout & Neutral & N/A \\
\hline
\end{tabular}

In all scenarios except for one, founders' stock is either disadvantaged or whatever advantage exists is minimal. The single scenario where founders' stock is significantly advantaged is the false start case, which is discussed further in Part IV.

The analysis thus far has focused on ex post results-i.e., whether the utilization of either founders' stock or stock options turns out, with the benefit of hindsight, to have been tax-advantageous. Of course, when choosing ex ante whether to use stock or options, the parties cannot know what will happen in the future. They must choose their structure in the face of this uncertainty. Based on our analysis, it appears that the choice about whether to use founders' stock or stock options depends mostly on the relative likelihoods of generating a home run or a false start. ${ }^{104}$ Singles, doubles, triples, and strikeouts can safely be ignored as the net advantage or disadvantage in these cases is relatively minor.

The fact that founders and venture capital firms routinely utilize founders' stock rather than stock options would seem to imply that founders' stock must be tax-advantaged ex ante (that is, on an expectedvalue basis). After all, venture capital participants have significant financial

104. In addition, the amount of expected tax advantage must be assessed. Thus, for example, even if a false start is ten times as likely as a home run, if the expected tax advantage from a home run (should one occur) equals twenty times the expected false start advantage (should one occur), then NQSOs would still be tax-advantaged. 
incentives to maximize tax efficiency. On the other hand, there is evidence that venture capital practices are quite rigid. ${ }^{105}$ The resulting inertia may explain the persistence of tax-inefficient structures. For example, some have argued that venture capital practices unnecessarily leave significant tax money on the table by insisting on the corporate form ${ }^{106}$ and by separately incorporating each venture. ${ }^{107}$ Industry standardization may be the best explanation for the perpetuation of tax-inefficient structures, and it may also explain the pervasive use of founders' stock.

\section{ASSESSMENT OF DESCRIPTIVE RESUlTS}

\section{A. IS THE NET TAX SAVINGS IN THE FALSE START SCENARIO A NORMATIVE TAX ADVANTAGE?}

In Part III, we showed that the only one of our hypothetical scenarios that yields a significant overall tax advantage for founders' stock is the false start case. In that scenario, the company's stock appreciates based on the expectation of significant profitability, resulting in a successful IPO or takeover, but the profitability either never materializes or it materializes too slowly for the company's tax deductions to have much value. Nevertheless, the founder is able to liquidate a substantial portion of her equity stake in the company while the stock price is high. In that case, a founder receiving founders' stock realizes the benefit of character conversion, but the company does not suffer a significant detriment because the foregone deductions would have had little value.

While use of the founders' stock structure in the false start scenario generates a net tax savings to the parties, a broader perspective shows that this result is not a cause for concern. In fact, the tax advantage here is best characterized not as a benefit or subsidy, but rather as a mitigation of the harsh treatment of losses suffered by failed corporations under existing law.

When a corporation fails with unused net operating losses, or if the losses expire before the company is able to use them under existing law, the losses evaporate. One could easily envision an alternative tax rule that refunded losses when a corporation liquidates with unused losses. ${ }^{108}$ For

\footnotetext{
105. See, e.g., Gilson \& Schizer, supra note 1, at 881 (noting, in the context of discussing venture capital practices, the tendency of contracts to become standardized); Johnson, supra note 10 , at $60-61$ (describing the standardization of venture capital legal practices).

106. See Daniel S. Goldberg, Choice of Entity for a Venture Capital Startup: The Myth of Incorporation, 55 TAX LAW. 923 (2002); Johnson, supra note 10. For additional discussion of why venture capitalists traditionally use the corporate form despite its apparent tax inefficiency, see Victor Fleischer, The Rational Exuberance of Structuring Venture Capital Startups, 57 TAX L. REV. $137(2003)$.

107. See, e.g., Joseph Bankman, The Structure of Silicon Valley Startups, 41 UCLA L. REV. 1737 , 1738 (1994); Johnson, supra note 10.

108. See Cooper \& Knittel, supra note 9o, at $65^{2}$ ("In theory, corporate income tax systems could allow any degree of loss utilization ranging from zero to full loss refundability.").
} 
example, a corporation that liquidates with $\$ 1,000$, ooo of unused losses would receive a tax refund of $\$ 35^{\circ}$, ooo on the theory that if the corporation had earned $\$ 1,000$,ooo in profits, it would have faced a $\$ 35^{\circ}$,ooo tax liability. ${ }^{109}$ Refunding losses in this manner makes sense from both a fairness and efficiency standpoint. ${ }^{10}$ The government is effectively a business partner with the corporation in the event of profits; fairness would seem to dictate that it should also be a partner in the event of losses. ${ }^{\prime \prime}$ To the extent that nonrefundability of losses is grounded in concerns over manipulation of the realization rule, the opportunity for manipulation decreases significantly if nonrefundability is deferred until the corporation terminates its existence through liquidation. From an economic-efficiency standpoint, the failure to refund losses discourages optimal risk-taking behavior because the government will take its share of winning bets but does not participate in losing bets. ${ }^{112}$ This asymmetrical regime deters some risks that have a positive pretax expected value, which is an inefficient result. ${ }^{113}$

Even if a company eventually is able to utilize losses, the current tax rules are suboptimal. Net operating losses are not adjusted for the time value of money. Thus, an immediate deduction of $\$ 100$, which would result in $\$ 35$ of immediate tax savings if utilizable today, is worth only $\$ 11$ if it is used in twenty years, using a six percent discount rate. ${ }^{114}$ Absent refundability of losses, a second-best approach would be to adjust the amount of losses to reflect the time value of money. ${ }^{15}$ This would be more

109. This oversimplifies matters somewhat because the corporate tax rates are progressive to an extent. See I.R.C. $\$ 11$ (2006). But the overall point remains that losses could be refundable to the same extent that gains would have been taxed. See generally Mark Campisano \& Roberta Romano, Recouping Losses: The Case for Full Loss Offsets, 76 Nw. U. L. REV. 709 (1981) (arguing in favor of such a regime).

110. See Campisano \& Romano, supra note 109 , at $715^{-30}$ (making these arguments in favor of refundability); Cooper \& Knittel, supra note 9o, at 652-54 (explaining the efficiency gains from full refundability).

111. See Campisano \& Romano, supra note 109, at $7^{1} 5^{-22}$ (contending that current law's rule of nonrefundability is inequitable).

112. See id. at $722-30$ (explaining the inefficiency of nonrefundability); Cooper \& Knittel, supra note go, at $65^{2-54}$ (same).

1 13. Startups are particularly impacted by this incongruity because, unlike a mature and diversified firm, they cannot offset their losses against gains from other businesses. See Cooper \&c Knittel, supra note 90 , at 653 . The harsh tax treatment of unused losses also stands in sharp contrast to other legal structures (e.g., limited liability afforded to owners of business entities and bankruptcy protection) that mitigate the adverse effects from losing ventures in an attempt to facilitate optimal risk-taking.

114. See id. (noting the erosion of the value of unused losses due to the time value of money); Michael G. Cooper \& Matthew J. Knittel, The Implications of Tax Asymmetry for U.S. Corporations, 63 NAT'L TAX J. 33, 35 (2010) (contending that "the most conspicuous deficiency is the real NOL erosion caused by delays in claiming carryforward deductions").

1 15. See Cooper \& Knittel, supra note 114, at 35 (explaining that "no OECD country that levies a corporate income tax allows full NOL refundability or even pays interest to maintain their real values"). 
equitable than the current system, where the government gets its share of winnings immediately but effectively does not have to pay its share of the losses until later. ${ }^{16}$ It would also increase efficiency relative to the current system because it would make the tax law more neutral regarding the decision to invest in risky enterprises.

The current tax system therefore subjects net losses to two harsh rules: losses are nonrefundable, and they are not adjusted for inflation over time. Both rules are difficult to justify on equitable or efficiency grounds. ${ }^{117}$ They persist nevertheless, presumably because of practical concerns: they generate additional tax revenue for the government, and they limit the opportunity for taxpayer fraud. ${ }^{18}$ In cases of real (that is, nonfraudulent) losses, these harsh rules effectively serve as a tax penalty on firms that fail or are slow to reach profitability." Typically, whatever global tax advantage stems from founders' stock in a particular situation exists only because of this penalty. Consider the false start case, which involves a startup that eventually fails with significant unused losses. If losses were fully refundable, as is theoretically appropriate, the tax advantage would disappear. Thus, if we use the facts in the false start case but add the refundability of losses in Year 12 when the company fails, the \$20 million tax advantage for founders' stock turns into a $\$ 3$ million disadvantage, as shown in the Appendix. ${ }^{120}$ Likewise, if we use the facts in the "single" example, but use the second-best approach of adjusting losses for inflation, the nearly $\$ 100,000$ net tax advantage for founders' stock becomes a net tax detriment to the parties of roughly $\$ 600,000 .^{12 !}$

In summary, the global tax advantage for founders' stock in the false start cases is a result of the unduly harsh treatment of losses under current law. Thus, in cases in which the use of founders' stock generates a net reduction in tax for the parties, the government gains a much greater advantage through its improper treatment of losses. If the punitive treatment of losses under the existing law were eliminated, the net tax savings from the use of founders' stock in a false start scenario would be eliminated as well. Thus, we view the tax advantage in the false start context (and in other similar situations) to be a normatively acceptable mitigation of

116. However, it would be second best to a system of full refundability because inflationadjusted losses would not be fully remedial in cases where the company does not eventually earn an overall profit.

117. Cooper \& Knittel, supra note 9o, at 654 (noting that "there is no theoretical justification for the disallowance of full refundability").

118. See id. Fraud is limited under the current system because the government does not issue refund checks in the case of claimed losses. Thus, the payoff for manufacturing fake losses is limited to the amount of tax that would otherwise be due. See id.

119. See id. (calling the current nonrefundability rule an "implicit penalty imposed on firms" that have delayed or underutilized losses).

120. See infra Appendix, Part VI.

121. See infra Appendix, Part VII. 
an unwarranted tax penalty, rather than an unjustified tax advantage in need of remedy.

\section{B. THE POTENTIAL FOR MARKET FAILURE}

To determine whether a transaction structure is tax-advantaged, the multilateral perspective considers the tax consequences of all parties to the transaction. ${ }^{122}$ If, by virtue of using one structure over another, one party achieves a benefit but the other party bears an equal and offsetting burden, the tax consequences between the two transactions are economically identical. ${ }^{123}$ One might worry that by shifting a tax benefit or burden from one party to another, the "wrong" party ends up being taxed. If so, one side of the transaction would receive an unwarranted burden (additional tax liability) and the other a windfall (reduced tax liability). However, in the usual case, there is no need to worry about any such misallocation of legal liability for the tax because the parties will adjust their pricing to take into account the changed tax circumstances. ${ }^{124}$ In other words, the parties will bargain around the tax rules to achieve the same after-tax results as before.

Thus, the identity of the party who formally remits tax dollars to the government is generally not economically significant. ${ }^{25}$ But there are some exceptions to this general rule. If pretax pricing is inelastic, then adjusting for a shifting of the formal tax incidence could be difficult. For example, pre-tax pricing might be sticky as a result of legal restrictions. Consider minimum-wage laws. If Congress changed the income tax from a tax on receiving income to a tax on paying wages, one would generally expect wages to adjust to reflect the shifting of the nominal tax burden from employees to employers. But if the current minimum-wage laws remained in effect despite this tax change, wages for low-paying jobs could not fully adjust because they would hit the minimum-wage floor, resulting in an aftertax distortion. In such a case, a change in formal incidence would matter.

Another situation where a change in formal incidence would be economically significant is where the burdened side of the transaction is not sufficiently aware of the change to properly react to it. In that case, the burdened party would not have enough information to demand the

122. See supra note 7 and accompanying text (describing the multilateral or joint tax perspective).

123. See GRUBER, supra note 7 , at 519-27 (explaining that the formal incidence of a tax "is irrelevant to the distribution of the tax burdens").

124. See Chason, supra note 53 , at 1675 ("One can safely disregard any fairness concerns about the allocation of tax burdens of the executive or the employer because the parties are financially sophisticated and able to adjust their transaction in response to the formal incidence of any tax."); Yale \& Polsky, supra note 7 , at 580 (noting, in the context of compensation for services, that the side of the transaction on which a tax burden is imposed or a tax benefit conferred is irrelevant because "the parties can adjust the nominal pretax compensation to shift the tax benefits and burdens between themselves").

125. See GRUBER, supra note 7 , at 580 . 
necessary change in prices. Normally, however, information problems are not a concern in the context of sophisticated parties who have the resources to become sufficiently informed about potential tax consequences. ${ }^{126}$

Professor Fleischer nevertheless has argued that formal incidence in the context of founders' stock is significant even though the parties appear highly sophisticated.127 Fleischer contends that the unilateral tax advantage to founders remains problematic even where founders' stock is disadvantaged overall. In other words, Fleischer is concerned about the tax advantage enjoyed by founders in the home run scenario, ${ }^{128}$ even though the use of founders' stock by the parties proves to be wildly profitable for the government in those cases.

Fleischer contends that the market price of the company's stock at the IPO does not fully reflect the absence of the compensation deductions resulting from the issuance of founders' stock. ${ }^{29}$ In other words, the market does not sufficiently "miss" the foregone deductions when founders' stock is used in lieu of stock options. The market therefore does not sufficiently punish the stock price of the company for the absence of these deductions on the company's balance sheet, resulting in an overpricing of the company stock. Had the market sufficiently punished the stock, it would discipline founders and venture capitalists to not use founders' stock as a form of disguised compensation when other traditional forms of equity compensation are more tax efficient. Yet because the forfeited deductions do not affect the market price, no pressure exists to employ the most taxefficient structure. In short, the market is playing the role of sucker to the founders' tax benefit.

Hence, in Fleischer's account, while it is true that the government may be collecting the same (or even much more) tax revenue from the use of founders' stock overall, the detriment is being borne by the wrong partythat is, whoever bears the burden of the company's increased corporate income tax liability. ${ }^{13^{\circ}}$ Due to the obscure nature of who actually bears the tax detriment, the use of founders' stock appears to yield a windfall for the founders, who come away from the transaction with a readily identifiable tax benefit.

126. See Chason, supra note 53 , at 1675 (explaining that, in the executive compensation context, "one can safely disregard any fairness concerns about the allocation of tax burdens ... because the parties are financially sophisticated and able to adjust their transaction in response to the formal incidence of any tax").

1 27. Fleischer, supra note 4 , at go (arguing that the joint tax perspective "does not assuage distributive justice concerns" because of the failure of the market to correctly price the company's stock absent the missing tax deductions).

1 28. Id. at 89-91 (targeting criticism at "home run" cases).

129. Id. at 90-91 (contending that market prices do not reflect the missing deductions).

130. See id. at 91 (explaining that, because of the market's mispricing of company stock, " $[\mathrm{t}]$ he economic burden of the lost tax deduction is shifted from founders to public shareholders (or other stakeholders burdened by the corporate tax)"). 


\section{Questioning the Account}

The issue of whether the market sufficiently values tax assets ${ }^{131}$ namely, in this setting, deductions attributable to traditional forms of equity compensation such as stock options-ultimately presents a daunting empirical inquiry that we do not undertake. ${ }^{132}$ Nonetheless; for reasons discussed below, our intuition is that the amount of market mispricing is not significant.

To start, market participants have significant incentives not to misprice the value of tax assets. ${ }^{133}$ Because IPO underwriters are paid a percentage of the proceeds generated by the IPO,134 they have significant financial incentives to present all information that could make the company more attractive to investors-including favorable tax information.135 Likewise, venture capitalists would want to maximize the IPO price to maximize their own profits. ${ }^{136}$ If deductions were available for future use, one would expect that underwriters and venture capitalists would work hard to ensure that the market appreciated their full value. ${ }^{137}$ Furthermore, even if tax assets remained substantially underpriced in spite of these incentives, one would expect arbitrageurs to exploit this inefficiency by buying companies with underpriced tax assets and then selling the companies after the tax assets have been monetized. This arbitraging would bid up the price of tax assets to the point at which they are valued correctly. In short, there are a number of market participants who would seem to have significant financial incentives to appropriately price tax assets.

\footnotetext{
131. In addition to Fleischer's concern about market mispricing, Calvin Johnson has similarly noted the possibility that "public owners of the corporation may not notice the loss [of compensation deductions] or be able to protect themselves." Johnson, supra note 10 , at 69 . However, Johnson ultimately expressed skepticism about "the benefit to be gained [by founders] in trying to fool the market." Id.

132. It would be extremely difficult to prove the counterfactual that the market would substantially undervalue the company's foregone deductions. Cf. Peter A. Furci \& Jeffrey J. Rosen, Monetizing the Shield, DEAL MAG. (Mar, 3, 2011), http://www.thedeal.com/magazine/ ID $/{ }_{3} 85_{5}^{6}$ /community/monetizing-the-shield.php (describing the extreme difficulty in determining whether, and the extent to which, the market underprices tax assets).

133. See Stephen M. Bainbridge, Executive Compensation: Who Decides?, 83 TEX. L. REV. 1615 , 1637 (2005) (reviewing LUCIAN BEBCHuK \& JESSE FRIED, PAY Without PERFormance: ThE UNFILLED PROMISE OF EXECUTIVE COMPENSATION (2004)) (noting that venture capitalists and underwriters are key participants in the IPO process and that "[i]t is in the interest of such actors to maximize the price at which the company goes public").
}

134. See Jeffrey N. Gordon, The Mandatory Structure of Corporate Law, 89 CoLuM. L. REV. $1549,1559(1989)$.

135. Cf. id. (explaining that because "the underwriter's compensation is a percentage of the offering price, ... the underwriter has an independent incentive to discourage the inclusion of charter terms that might reduce the [IPO] price").

136. See Bainbridge, supra note 133, at 1637 (noting that venture capitalists have incentives to maximize IPO prices).

137. Cf. id. at $1636-37$ (arguing that key participants in IPOs would insist on efficient constraints on managerial power in order to maximize the IPO price). 
In support of his claim that the market substantially undervalues the company's foregone deductions, Fleischer cites the occasional use of tax receivable agreements ("TRAs") in some recent IPOs. ${ }^{13^{8}}$ These agreements effectively allocate the tax benefits of existing or future tax deductions back to the original (that is, pre-IPO) shareholders. ${ }^{139}$ As a result of TRAs, the deductions are excluded from the sale, allowing the market to disregard them in valuing the stock. While the existence of TRAs in some deals does evidence at least some difficulty in the pricing of tax assets, we believe that Fleischer overstates the implications that follow from the TRAs.

First, Fleischer suggests that the existence of TRAs indicates that markets pervasively value the future tax benefits of deduction at zero..$^{10}$ However, this conclusion is inconsistent with the fact that TRAs are the exception to the norm, which is to not use a TRA, despite the pervasiveness of tax assets. More importantly, in those relatively few cases where a TRA is used, the use implies merely that the market has valued the tax assets at a sufficiently lower value than the original shareholders to justify the transaction costs of the TRA. The amount of any such discount in any particular case is extremely difficult to ascertain. ${ }^{1{ }^{1}}$

Furthermore, even in those cases where TRAs are used, the amount of mispricing may not be significant. Tax lawyers Jeffrey Rosen and Peter Furci advise that, except in certain narrow contexts, the complexity of TRAs may not be justified by the amount of mispricing. ${ }^{14^{2}}$ They therefore conclude that in most contexts, "sponsors should consider the relative advantages of using TRAs versus providing more detail on the expected utilization of tax attributes in an effort to cause them to be properly valued in the offering price." ${ }^{143}$ This recommendation implies that whatever mispricing would persist after full disclosure and explanation of tax attributes would be relatively minor.

Finally, the absence of TRAs regarding founders' compensation suggests that whatever pricing anomaly may exist in that particular context is not significant. Assume for a moment that markets would indeed regularly and significantly undervalue tax deductions stemming from stock options

\footnotetext{
138. See Fleischer, supra note 4 , at 9o-91.

139. See Furci \& Rosen, supra note 132.

140. See Fleischer, supra note 4 , at 91 (arguing that TRAs suggest that "founders likely do not pay an implicit tax in the form of a reduced price at IPO"). While Fleischer suggests that, if markets adequately priced tax assets, the only form of implicit tax paid by founders would be in the form of reduced IPO price, this may not be true. Presumably, founders would also receive a smaller equity stake than if they had been paid in NQSOs, because venture capitalists would take account of the founders' tax benefit and the related effect on the company's expected IPO price.

141. See Furci \& Rosen, supra note 132.

142. See id.

143. Id.
} 
issued to founders. ${ }^{144}$ If so, founders and venture capitalists would be better off using stock options (in lieu of founders' stock) and then, at the IPO, employing TRAs to buy the associated future tax deductions from the market at a discounted price. If the market significantly undervalues future tax deductions, the profits from exploiting this inefficiency through a direct purchase would exceed the cost to founders of realizing ordinary income rather than capital gains. Crudely put, it is far more profitable to "steal" deductions that give you thirty-five cents on the dollar rather than transmuting ordinary income to capital gains and thereby saving only twenty-two cents on the dollar. ${ }^{145}$

Thus, if Fleischer's account of market mispricing of tax assets is correct, current venture capital practices are puzzling. ${ }^{14^{6}}$ Under his account, founders and venture capitalists are aware of the mispricing of tax assets; that is why they use founders' stock even though it deprives the company of valuable tax assets. However, instead of exploiting this flaw directly by using stock options combined with TRAs, founders and venture capitalists exploit it indirectly through the use of founders' stock-even though this approach also provides the government with a share of the resulting gains (by subjecting disguised compensation income to taxation at capital gains rates). There appears to be no good reason why founders and venture capital firms would choose to leave so much money on the table.

\section{Even Assuming the Account Is True, Does It Justify a Tax Response?}

Even assuming for purposes of argument that Fleischer's account of widespread significant mispricing of tax assets is correct, we do not believe that tax reform is the appropriate response. To start, one would expect that whatever market failure currently exists through the mispricing of tax assets will eventually resolve itself over time. There is no reason to suspect that, as an institutional matter, founders and venture capitalists would be better than the market at pricing tax assets. Absent such an institutional advantage, any such mispricing that occurs should be temporary. ${ }^{147}$

\footnotetext{
144. Again, it must be emphasized that if this were true, TRAs would always be used whenever IPO companies have any substantial tax assets, such as net operating loss carryforwards. Yet, the literature indicates that TRAs remain the exception rather than the norm, except in specific contexts, such as those involving variations on the so-called UPREIT structure. See id.

145. This comparison assumes that the transaction costs associated with the TRA and the issuance of founders' stock are the same, which admittedly may not be the case.

146. Note that it has been argued that other venture capital practices are likewise not easily rationalized. See supra notes $104-07$ and accompanying text.

147. See Amy S. Elliott, IPO Agreements That Shift Basis Step-Up to Sellers Proliferate, $3_{2}$ TAX NoTES 334, 339 (2011) (describing a tax practitioner's view that "as the [tax receivables agreement] strategy gains wider acceptance, ... . the market [will] become more sophisticated in its ability to price tax attributes into the offering price").
} 
Yet even if markets do not fully develop to properly value tax assets, fixing whatever distributional problem remains through tax reform would be extremely difficult, as Fleischer himself acknowledges. ${ }^{14^{8}}$ Fleischer's suggestion is to fundamentally change the tax system. ${ }^{149}$ Even assuming that Fleischer's account is both accurate and permanent, tax reform of this order is an extremely blunt remedy to address the alleged agency cost imposed by founders on the other stakeholders of their companies-one that does not pose a meaningful threat to government tax revenue (and in fact is probably revenue enhancing). Justifying structural change to the tax system on the intuition that the public market is forever incapable of adequately pricing tax assets would be excessive in our view.

\section{CONCLUSION}

In this Article, we have argued that the current tax treatment of founders' stock is not a cause for concern. While founders receive a tax advantage from receiving founders' stock, their companies bear a corresponding burden in paying it. Whether the founder's benefit ultimately outweighs the company's burden in a particular case depends on a variety of facts, though it is clear that in Google-type home run cases, the net aggregate result for the founders and the company is profoundly negative. Furthermore, even in cases in which there is an overall advantage, the tax advantage occurs only because of the tax law's improper treatment of losses. Thus, whatever tax advantage exists for founders' stock is best viewed as a partial move towards the optimal treatment of tax losses, not as a standalone tax benefit that needs to be eliminated.

148. See Fleischer, supra note 4 , at 100.

149. See id. (recommending a shift to a consumption tax or dual income tax). 


\section{APPENDIX}

The calculations in this Appendix proceed on the following assumptions and simplifying conventions:

1. A $6 \%$ discount rate;

2. Constant tax rates of $15 \%$ for individual capital gains; $37.9 \%$ for compensation income; and $35 \%$ for corporate income tax;

3. The $\$ 25$, ooo purchase price (in Year o for founders' stock and in year of disposition for stock options) is disregarded; and

4. Once profitability is reached, the company remains profitable thereafter.

\section{HOME RUN}

Table 1 1: Facts

\begin{tabular}{|c|c|c|c|c|}
\hline $\begin{array}{c}\text { Time } \\
\text { from } \\
\text { Issuance }\end{array}$ & Event & $\begin{array}{l}\text { Stock Value } \\
\text { Relative to } \\
\text { Previous Event } \\
\text { (Annual IRR) }\end{array}$ & $\begin{array}{c}\text { Company } \\
\text { Attained } \\
\text { Profitability? }\end{array}$ & $\begin{array}{c}\text { Stock } \\
\text { Disposition } \\
\text { by Founder? }\end{array}$ \\
\hline o & Issuance & $\mathrm{N} / \mathrm{A}$ & No & No \\
\hline 5 & IPO & $50 x(119 \%)$ & No & $\begin{array}{l}1 / 3 \text { of } \\
\text { original } \\
\text { stake }\end{array}$ \\
\hline 10 & $\begin{array}{c}\text { Point of } \\
\text { Profitability }\end{array}$ & $2 \times(15 \%)$ & Yes & $\begin{array}{l}1 / 3 \text { of } \\
\text { original } \\
\text { stake }\end{array}$ \\
\hline 40 & Death & $7 \times(6.7 \%)$ & Yes & $\begin{array}{l}1 / 3 \text { of } \\
\text { original } \\
\text { stake }\end{array}$ \\
\hline
\end{tabular}


Table 12: Tax Benefit to Founders if Founders' Stock Is Used in Lieu of Options

\begin{tabular}{|c|c|c|c|}
\hline $\begin{array}{l}(1) \\
\text { Time }\end{array}$ & 5 & 10 & $4^{\circ}$ \\
\hline $\begin{array}{c}\text { (2) } \\
\text { Event }\end{array}$ & IPO & $\begin{array}{c}\text { Point of } \\
\text { profitability }\end{array}$ & Death \\
\hline $\begin{array}{c}\text { (3) } \\
\text { Number of } \\
\text { Shares Disposed } \\
\text { of }\end{array}$ & $\begin{array}{l}1 / 3 \text { of original } \\
\text { stake }\end{array}$ & $\begin{array}{l}1 / 3 \text { of original } \\
\text { stake }\end{array}$ & $\begin{array}{c}\text { 1/3 of original } \\
\text { stake }\end{array}$ \\
\hline $\begin{array}{l}(4) \\
\text { Proceeds }\end{array}$ & $\begin{array}{l}\$ 5,000,000 \\
\times 50 \times 1 / 3= \\
\$ 83,333,333\end{array}$ & $\begin{array}{c}\$ 5,000,000 \\
\times 100 \times 1 / 3= \\
\$ 166,666,667\end{array}$ & $\begin{array}{c}\$ 5,000,000 \\
\times 700 \times 1 / 3= \\
\$ 1,166,666,667\end{array}$ \\
\hline $\begin{array}{c}(5) \\
\text { Tax if Founders' } \\
\text { Stock Were Used }\end{array}$ & $\begin{array}{c}\$ 83,333,333 \\
\times 15 \%= \\
\$ 12,500,000\end{array}$ & $\begin{array}{c}\$ 166,666,667 \\
\times 15 \%= \\
\$ 25,000,000\end{array}$ & $\begin{array}{l}\text { \$o (because of } \\
\text { stepped-up } \\
\text { basis at death) }\end{array}$ \\
\hline $\begin{array}{c}(6) \\
\text { Tax if Stock } \\
\text { Options Were } \\
\text { Used }\end{array}$ & $\begin{array}{c}\$ 83,333,333 \\
\times 37 \cdot 9 \%= \\
\$ 31,583,333\end{array}$ & $\begin{array}{c}\$ 166,666,667 \\
\times 37.9 \%= \\
\$ 63,166,667\end{array}$ & $\begin{array}{c}\$ 1,166,666,667 \\
\times 37 \cdot 9 \%= \\
\$ 44^{2,1} 66,667\end{array}$ \\
\hline $\begin{array}{c}(7) \\
\text { Tax Savings from } \\
\text { FS } \\
{[(6)-(5)]}\end{array}$ & $\$ 19,083,333$ & $\$ 38,166,667$ & $\$ 44^{2,166,667}$ \\
\hline $\begin{array}{c}(8) \\
\text { Present Value of } \\
\text { Tax Savings at } \\
\text { Time o }\end{array}$ & $\$ 14,260,177$ & $\$ 21,312,067$ & $\$ 4^{2,988,4^{11}}$ \\
\hline \multicolumn{3}{|c|}{$\begin{array}{l}\text { Total Tax Benefit from Use of Founders' Stock } \\
\text { (Time o dollars) [Sum of the Values in Row 8] }\end{array}$} & $\$ 78,560,655$ \\
\hline
\end{tabular}


Table 13: Tax Detriment to Company if Founders' Stock Is Used in Lieu of Options

\begin{tabular}{|c|c|c|c|}
\hline $\begin{array}{l}\text { (1) } \\
\text { Time }\end{array}$ & 5 & 10 & $4^{\circ}$ \\
\hline $\begin{array}{c}(2) \\
\text { Event }\end{array}$ & IPO & $\begin{array}{c}\text { Point of } \\
\text { profitability }\end{array}$ & Death \\
\hline $\begin{array}{c}(3) \\
\text { Number of Shares } \\
\text { Disposed of }\end{array}$ & $\begin{array}{l}1 / 3 \text { of } \\
\text { original stake }\end{array}$ & $\begin{array}{l}1 / 3 \text { of original } \\
\text { stake }\end{array}$ & $\begin{array}{l}1 / 3 \text { of original } \\
\text { stake }\end{array}$ \\
\hline $\begin{array}{l}(4) \\
\text { Proceeds }\end{array}$ & $\begin{array}{l}\$ 5,000,000 \\
\times 50 \times 1 / 3= \\
\$ 83,333,333\end{array}$ & $\begin{array}{c}\$ 5, \text { ooo,ooo } \\
\times 100 \times 1 / 3= \\
\$ 166,666,667\end{array}$ & $\begin{array}{c}\$ 5,000,000 \\
\times 700 \times 1 / 3= \\
\$ 1,166,666,667\end{array}$ \\
\hline $\begin{array}{c}(\mathbf{5}) \\
\text { Deductions if } \\
\text { Founders' Stock } \\
\text { Were Used }\end{array}$ & \$o & $\$ 0$ & $\$ 0$ \\
\hline $\begin{array}{c}(6) \\
\text { Deductions if Stock } \\
\text { Options Were Used }\end{array}$ & $\$ 83,333,333$ & $\$ 166,666,667$ & $\$ 1,166,666,667$ \\
\hline $\begin{array}{c}(7) \\
\text { Tax Cost of FS: } \\
{[(6)-(5)] \times 35 \%} \\
\text { starting in Year } 10\end{array}$ & $\$ o^{a}$ & 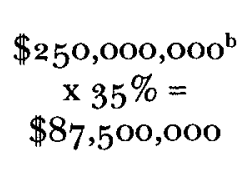 & $\$ 408,333,333$ \\
\hline $\begin{array}{c}(8) \\
\text { Present Value of } \\
\text { Tax Cost at Time } 0\end{array}$ & \$o & $\$ 48,859,543$ & $\$ 39,699,060$ \\
\hline \multicolumn{3}{|c|}{$\begin{array}{l}\text { Total Tax Detriment from Use of Founders' Stock } \\
\text { (Time o dollars) [Sum of the Values in Row 8] }\end{array}$} & $\$ 88,55 \underline{8,603}$ \\
\hline
\end{tabular}

a. There are no tax savings in Year 5 because the company is still in a loss position. The deductions from Year 5 carry over to Year 10 and are used then, together with the deductions generated in Year 10.

b. This value includes $\$ 83,333,333$ of deductions that carry over from Year 5 and the $\$ 166,666,667$ of deductions from Year 10. 
II. TRIPLE

Table 14: Facts

\begin{tabular}{|c|c|c|c|c|}
\hline $\begin{array}{c}\text { Time } \\
\text { from } \\
\text { Issuance }\end{array}$ & Event & $\begin{array}{c}\text { Stock Value } \\
\text { Relative to } \\
\text { Previous Event } \\
\text { (Annual IRR) }\end{array}$ & $\begin{array}{c}\text { Company } \\
\text { Attained } \\
\text { Profitability? }\end{array}$ & $\begin{array}{c}\text { Stock } \\
\text { Disposition } \\
\text { by Founder? }\end{array}$ \\
\hline 0 & Issuance & N/A & No & No \\
\hline 5 & IPO & $25 \times(90 \%)$ & No & $\begin{array}{c}1 / 3 \text { of } \\
\text { original } \\
\text { stake }\end{array}$ \\
\hline 13 & $\begin{array}{c}\text { Point of } \\
\text { Profitability }\end{array}$ & $2 \times(9 \%)$ & Yes & $\begin{array}{c}1 / 3 \text { of } \\
\text { original } \\
\text { stake }\end{array}$ \\
\hline 40 & Death & $6 \times(6.9 \%)$ & Yes & $\begin{array}{c}1 / 3 \text { of } \\
\text { original } \\
\text { stake }\end{array}$ \\
\hline
\end{tabular}


Table 15: Tax Benefit to Founders if Founders' Stock Is Used in Lieu of Options

\begin{tabular}{|c|c|c|c|}
\hline $\begin{array}{l}\text { (1) } \\
\text { Time }\end{array}$ & 5 & 13 & $4^{\circ}$ \\
\hline $\begin{array}{c}(\mathbf{2}) \\
\text { Event }\end{array}$ & IPO & $\begin{array}{l}\text { Point of } \\
\text { profitability }\end{array}$ & Death \\
\hline $\begin{array}{c}\text { (3) } \\
\text { Number of } \\
\text { Shares Disposed } \\
\text { of }\end{array}$ & $\begin{array}{l}\text { 1/3 of original } \\
\text { stake }\end{array}$ & $\begin{array}{l}1 / 3 \text { of original } \\
\text { stake }\end{array}$ & $\begin{array}{l}\text { 1/3 of original } \\
\text { stake }\end{array}$ \\
\hline $\begin{array}{l}(4) \\
\text { Proceeds }\end{array}$ & $\begin{array}{c}\$ 5,000,000 \\
\times 25 \times 1 / 3= \\
\$ 41,666,667\end{array}$ & $\begin{array}{l}\$ 5,000,000 \\
\times 50 \times 1 / 3= \\
\$ 83,333,333\end{array}$ & $\begin{array}{c}\$ 5,000,000 \\
\times 300 \times 1 / 3= \\
\$ 5^{00,000,000}\end{array}$ \\
\hline $\begin{array}{c}(5) \\
\text { Tax if Founders' } \\
\text { Stock Were Used }\end{array}$ & $\begin{array}{c}\$ 41,666,667 \\
\times 15 \%= \\
\$ 6,25^{0,000}\end{array}$ & $\begin{array}{c}\$ 83,333,333 \\
\times 15 \%= \\
\$ 12,5 \text { oo,ooo }\end{array}$ & $\begin{array}{l}\text { \$o (because of } \\
\text { stepped-up } \\
\text { basis at death) }\end{array}$ \\
\hline $\begin{array}{c}(6) \\
\text { Tax if Stock } \\
\text { Options Were } \\
\text { Used }\end{array}$ & $\begin{array}{c}\$ 41,666,667 \\
\times 37 \cdot 9 \%= \\
\$ 15,791,667\end{array}$ & $\begin{array}{c}\$ 83,333,333 \\
\times 37.9 \%= \\
\$ 31,583,333\end{array}$ & $\begin{array}{c}\$ 500,000,000 \\
\times 37 \cdot 9 \%= \\
\$ 189,5 \text { oo,ooo }\end{array}$ \\
\hline $\begin{array}{c}(7) \\
\text { Tax Savings from } \\
\text { FS } \\
{[(6)-(5)]}\end{array}$ & $\$ 9,54^{1}, 667$ & $\$ 19,083,333$ & $\$ 189,5$ Oo,ooo \\
\hline $\begin{array}{c}(8) \\
\text { Present Value of } \\
\text { Tax Savings at } \\
\text { Time o }\end{array}$ & $\$ 7,130,089$ & $\$ 8,947,011$ & $\$ 18,4^{23}, 605$ \\
\hline \multicolumn{3}{|c|}{$\begin{array}{l}\text { Total Tax Benefit from Use of Founders' Stock } \\
\text { (Time o dollars) [Sum of the Values in Row 8] }\end{array}$} & $\$ 34,500,705$ \\
\hline
\end{tabular}


Table 16: Tax Detriment to Company if Founders' Stock Is Used in Lieu of Options

\begin{tabular}{|c|c|c|c|}
\hline $\begin{array}{l}\text { (1) } \\
\text { Time }\end{array}$ & 5 & 13 & $4^{\circ}$ \\
\hline $\begin{array}{l}(\mathbf{2}) \\
\text { Event }\end{array}$ & IPO & $\begin{array}{l}\text { Point of } \\
\text { profitability }\end{array}$ & Death \\
\hline $\begin{array}{c}(3) \\
\text { Number of Shares } \\
\text { Disposed of }\end{array}$ & $\begin{array}{c}1 / 3 \text { of } \\
\text { original stake }\end{array}$ & $\begin{array}{l}1 / 3 \text { of original } \\
\text { stake }\end{array}$ & $\begin{array}{l}1 / 3 \text { of original } \\
\text { stake }\end{array}$ \\
\hline $\begin{array}{c}(4) \\
\text { Proceeds }\end{array}$ & $\begin{array}{l}\$ 5,000,000 \\
\times 25 \times 1 / 3= \\
\$ 41,666,667\end{array}$ & $\begin{array}{l}\$ 5,000,000 \\
\times 50 \times 1 / 3= \\
\$ 83,333,333\end{array}$ & $\begin{array}{c}\$ 5,000,000 \\
\times 300 \times 1 / 3= \\
\$ 500,000,000\end{array}$ \\
\hline $\begin{array}{c}(5) \\
\text { Deductions if } \\
\text { Founders' Stock } \\
\text { Were Used }\end{array}$ & $\$ 0$ & $\$ 0$ & $\$ 0$ \\
\hline $\begin{array}{c}(6) \\
\text { Deductions if Stock } \\
\text { Options Were Used }\end{array}$ & $\$ 4^{1,666,667}$ & $\$ 83,333,333$ & $\$ 5^{\circ 00,000,000}$ \\
\hline $\begin{array}{c}(7) \\
\text { Tax Cost of FS: } \\
{[(6)-(5)] \times 35 \%} \\
\text { starting in Year } 13\end{array}$ & $\$ o^{\mathrm{a}}$ & $\begin{array}{c}\$ 125,000,000^{b} \\
\times 35 \%= \\
\$ 43,750,000\end{array}$ & $\$ 175,000,000$ \\
\hline $\begin{array}{c}(8) \\
\text { Present Value of } \\
\text { Tax Cost at Time o }\end{array}$ & $\$ 0$ & $\$ 20,511,707$ & $\$ 17,013,882$ \\
\hline \multicolumn{3}{|c|}{$\begin{array}{l}\text { Total Tax Detriment from Use of Founders' Stock } \\
\text { (Time o dollars) [Sum of the Values in Row 8] }\end{array}$} & $\$ 37.525 .589$ \\
\hline
\end{tabular}

a. There are no tax savings in Year 5 because the company is still in a loss position. The deductions from Year 5 carry over to Year 13 and are used then, together with the deductions generated in Year 13.

b. This value includes $\$ 41,666,667$ of deductions that carry over from Year 5 and the $\$ 83,333,333$ of deductions from Year 13 . 
III. DOUBLE

Table 17: Facts

\begin{tabular}{|c|c|c|c|c|}
\hline $\begin{array}{c}\text { Time } \\
\text { from } \\
\text { Issuance }\end{array}$ & Event & $\begin{array}{c}\text { Stock Value } \\
\text { Relative to } \\
\text { Previous Event } \\
\text { (Annual IRR) }\end{array}$ & $\begin{array}{c}\text { Company } \\
\text { Attained } \\
\text { Profitability? }\end{array}$ & $\begin{array}{c}\text { Stock } \\
\text { Disposition } \\
\text { by Founder? }\end{array}$ \\
\hline 0 & Issuance & N/A & No & No \\
\hline 6 & IPO & $20 \times(65 \%)$ & No & $\begin{array}{c}1 / 3 \text { of } \\
\text { original } \\
\text { stake }\end{array}$ \\
\hline 20 & Point of & $2 \times(5.1 \%)$ & Yes & $\begin{array}{c}1 / 3 \text { of } \\
\text { original } \\
\text { stake }\end{array}$ \\
\hline 40 & Profitability & $4 \times(7.2 \%)$ & Yes & $\begin{array}{c}1 / 3 \text { of } \\
\text { original } \\
\text { stake }\end{array}$ \\
\hline
\end{tabular}


Table 18: Tax Benefit to Founders if Founders' Stock Is Used in Lieu of Options

\begin{tabular}{|c|c|c|c|}
\hline $\begin{array}{c}(\mathbf{1}) \\
\text { Time }\end{array}$ & 6 & 20 & 40 \\
\hline $\begin{array}{l}(\mathbf{2}) \\
\text { Event }\end{array}$ & IPO & $\begin{array}{l}\text { Point of } \\
\text { profitability }\end{array}$ & Death \\
\hline $\begin{array}{c}\text { (3) } \\
\text { Number of } \\
\text { Shares Disposed } \\
\text { of }\end{array}$ & $\begin{array}{l}1 / 3 \text { of original } \\
\text { stake }\end{array}$ & $\begin{array}{l}1 / 3 \text { of original } \\
\text { stake }\end{array}$ & $\begin{array}{l}1 / 3 \text { of original } \\
\text { stake }\end{array}$ \\
\hline $\begin{array}{l}(4) \\
\text { Proceeds }\end{array}$ & $\begin{array}{l}\$ 5,000,000 \\
\times 20 \times 1 / 3= \\
\$ 33,333,333\end{array}$ & $\begin{array}{l}\$ 5,000,000 \\
\times 40 \times 1 / 3= \\
\$ 66,666,667\end{array}$ & $\begin{array}{c}\$ 5,000,000 \\
\times 160 \times 1 / 3= \\
\$ 266,666,667\end{array}$ \\
\hline $\begin{array}{c}(5) \\
\text { Tax if Founders' } \\
\text { Stock Were Used }\end{array}$ & $\begin{array}{c}\$ 33,333,333 \\
\times 15 \%= \\
\$ 5, \text { ooo,ooo }\end{array}$ & $\begin{array}{c}\$ 66,666,667 \\
\times 15 \%= \\
\$ 10,000,000\end{array}$ & $\begin{array}{l}\text { \$o (because of } \\
\text { stepped-up } \\
\text { basis at death) }\end{array}$ \\
\hline $\begin{array}{c}(6) \\
\text { Tax if Stock } \\
\text { Options Were } \\
\text { Used }\end{array}$ & $\begin{array}{c}\$ 33,333,333 \\
\times 37 \cdot 9 \%= \\
\$ 12,633,333\end{array}$ & $\begin{array}{c}\$ 66,666,667 \\
\times 37 \cdot 9 \%= \\
\$ 25,266,667\end{array}$ & $\begin{array}{c}\$ 266,666,667 \\
\times 37.9 \%= \\
\$ 101,066,667\end{array}$ \\
\hline $\begin{array}{c}(7) \\
\text { Tax Savings from } \\
\text { FS } \\
{[(6)-(5)]}\end{array}$ & $\$ 7,633,333$ & $\$ \$_{5}, 266,667$ & $\$ 101,066,667$ \\
\hline $\begin{array}{c}(8) \\
\text { Present Value of } \\
\text { Tax Savings at } \\
\text { Time o }\end{array}$ & $\$ 5,381,199$ & $\$ 4,760,219$ & $\$ 9,825,922$ \\
\hline \multicolumn{3}{|c|}{$\begin{array}{l}\text { Total Tax Benefit from Use of Founders' Stock } \\
\text { (Time o dollars) [Sum of the Values in Row 8] }\end{array}$} & $\$ 19,967,340$ \\
\hline
\end{tabular}


Table 19: Tax Detriment to Company if Founders' Stock Is Used in Lieu of Options

\begin{tabular}{|c|c|c|c|}
\hline $\begin{array}{l}(1) \\
\text { Time }\end{array}$ & 6 & 20 & $4^{\circ}$ \\
\hline $\begin{array}{c}(\mathbf{2}) \\
\text { Event }\end{array}$ & IPO & $\begin{array}{l}\text { Point of } \\
\text { profitability }\end{array}$ & Death \\
\hline $\begin{array}{c}(3) \\
\text { Number of Shares } \\
\text { Disposed of }\end{array}$ & $\begin{array}{l}1 / 3 \text { of } \\
\text { original stake }\end{array}$ & $\begin{array}{l}1 / 3 \text { of original } \\
\text { stake }\end{array}$ & $\begin{array}{l}1 / 3 \text { of original } \\
\text { stake }\end{array}$ \\
\hline $\begin{array}{c}(4) \\
\text { Proceeds }\end{array}$ & $\begin{array}{l}\$ 5,000,000 \\
\times 20 \times 1 / 3= \\
\$ 33,333,333\end{array}$ & $\begin{array}{l}\$ 5,000, \text { ooo } \\
\times 40 \times 1 / 3= \\
\$ 66,666,667\end{array}$ & $\begin{array}{c}\$ 5,000,000 \\
\times 160 \times 1 / 3= \\
\$ 266,666,667\end{array}$ \\
\hline $\begin{array}{c}(5) \\
\text { Deductions if } \\
\text { Founders' Stock } \\
\text { Were Used }\end{array}$ & $\$ o$ & $\$ o$ & $\$ 0$ \\
\hline $\begin{array}{c}(6) \\
\text { Deductions if Stock } \\
\text { Options Were Used }\end{array}$ & $\$ 33,333,333$ & $\$ 66,666,667$ & $\$ 266,666,667$ \\
\hline $\begin{array}{c}(7) \\
\text { Tax Cost of FS: } \\
{[(6)-(5)] \text { x } 35 \%} \\
\text { starting in Year } 20\end{array}$ & $\$ o^{\mathrm{a}}$ & $\begin{array}{c}\$ 100,000,000^{b} \\
\times 35 \%= \\
\$ 35,000,000\end{array}$ & $\begin{array}{c}\$ 266,666,667 \\
\times 35 \%= \\
\$ 93,333,333\end{array}$ \\
\hline $\begin{array}{c}(\mathbf{8 )}) \\
\text { Present Value of } \\
\text { Tax Cost at Time o }\end{array}$ & $\$ o$ & $\$ 10,913,165$ & $\$ 9,074,071$ \\
\hline \multicolumn{3}{|c|}{$\begin{array}{l}\text { Total Tax Detriment from Use of Founders' Stock } \\
\text { (Time o dollars) [Sum of the Values in Row 8] }\end{array}$} & $\$ 19,987,236$ \\
\hline
\end{tabular}

a. No tax savings in Year 6 because the company is still in a loss position. The deductions from Year 6 carry over to Year 20 and are used then, together with the deductions generated in Year 20.

b. Includes $\$ 33,333,333$ of deductions that carry over from Year 6 and the $\$ 66,666,667$ of deductions from Year 20. 
IV. SINGLE

Table 20: Facts

\begin{tabular}{|c|c|c|c|c|}
\hline $\begin{array}{c}\text { Time } \\
\text { from } \\
\text { Issuance }\end{array}$ & Event & $\begin{array}{l}\text { Stock Value } \\
\text { Relative to } \\
\text { Previous Event } \\
\text { (Annual IRR) }\end{array}$ & $\begin{array}{c}\text { Company } \\
\text { Attained } \\
\text { Profitability? }\end{array}$ & $\begin{array}{c}\text { Stock } \\
\text { Disposition } \\
\text { by Founder? }\end{array}$ \\
\hline o & Issuance & $\mathrm{N} / \mathrm{A}$ & No & No \\
\hline 10 & IPO & $3 \times(11.6 \%)$ & No & $\begin{array}{l}1 / 3 \text { of } \\
\text { original } \\
\text { stake }\end{array}$ \\
\hline 30 & $\begin{array}{c}\text { Point of } \\
\text { Profitability }\end{array}$ & $3 \times(5 \cdot 7 \%)$ & Yes & $\begin{array}{l}1 / 3 \text { of } \\
\text { original } \\
\text { stake }\end{array}$ \\
\hline $4^{\circ}$ & Death & $2 \mathrm{x}(7.2 \%)$ & Yes & $\begin{array}{l}1 / 3 \text { of } \\
\text { original } \\
\text { stake }\end{array}$ \\
\hline
\end{tabular}


Table 21 : Tax Benefit to Founders if Founders' Stock Is Used in Lieu of Options

\begin{tabular}{|c|c|c|c|}
\hline $\begin{array}{c}(1) \\
\text { Time }\end{array}$ & 10 & $3^{\circ}$ & $4^{\circ}$ \\
\hline $\begin{array}{c}\text { (2) } \\
\text { Event }\end{array}$ & IPO & $\begin{array}{c}\text { Point of } \\
\text { profitability }\end{array}$ & Death \\
\hline $\begin{array}{c}\text { (3) } \\
\text { Number of } \\
\text { Shares Disposed } \\
\text { of }\end{array}$ & $\begin{array}{c}1 / 3 \text { of original } \\
\text { stake }\end{array}$ & $\begin{array}{l}1 / 3 \text { of original } \\
\text { stake }\end{array}$ & $\begin{array}{c}1 / 3 \text { of original } \\
\text { stake }\end{array}$ \\
\hline $\begin{array}{c}(4) \\
\text { Proceeds }\end{array}$ & $\begin{array}{l}\$ 5,000,000 \\
\times 3 \times 1 / 3= \\
\$ 5,000,000\end{array}$ & $\begin{array}{c}\$ 5,000,000 \\
\times 9 \times 1 / 3= \\
\$ 15,000,000\end{array}$ & $\begin{array}{l}\$ 5,000,000 \\
\times 18 \times 1 / 3= \\
\$ 30,000,000\end{array}$ \\
\hline $\begin{array}{c}\quad(5) \\
\text { Tax if Founders' } \\
\text { Stock Were Used }\end{array}$ & $\begin{array}{c}\$ 5,000,000 \\
\times 15 \%= \\
\$ 750,000\end{array}$ & $\begin{array}{c}\$ 15,000,000 \\
\times 15 \%= \\
\$ 2,25^{0,000}\end{array}$ & $\begin{array}{l}\text { \$o (because of } \\
\text { stepped-up } \\
\text { basis at death) }\end{array}$ \\
\hline $\begin{array}{c}(6) \\
\text { Tax if Stock } \\
\text { Options Were } \\
\text { Used }\end{array}$ & $\begin{array}{c}\$ 5,000, \text { OOO } \\
\times 37 \cdot 9 \%= \\
\$ 1,895,000\end{array}$ & $\begin{array}{c}\$ 15,000,000 \\
\times 37 \cdot 9 \%= \\
\$ 5,685,000\end{array}$ & $\begin{array}{c}\$ 30,000,000 \\
\times 37 \cdot 9 \%= \\
\$ 11,370,000\end{array}$ \\
\hline $\begin{array}{c}(7) \\
\text { Tax Savings from } \\
\text { FS } \\
{[(6)-(5)]}\end{array}$ & $\$ 1,145,000$ & $\$ 3,435,000$ & $\$ 11,370,000$ \\
\hline $\begin{array}{c}(8) \\
\text { Present Value of } \\
\text { Tax Savings at } \\
\text { Time o }\end{array}$ & $\$ 639,362$ & $\$ 598,068$ & $\$ 1,105,4^{16}$ \\
\hline \multicolumn{3}{|c|}{$\begin{array}{l}\text { Total Tax Benefit from Use of Founders' Stock } \\
\text { (Time o dollars) [Sum of the Values in Row 8] }\end{array}$} & $\$ 2,342,846$ \\
\hline
\end{tabular}


Table 22: Tax Detriment to Company if Founders' Stock Is Used in Lieu of Options

\begin{tabular}{|c|c|c|c|}
\hline $\begin{array}{c}\text { (1) } \\
\text { Time }\end{array}$ & 10 & $3^{\circ}$ & $4^{\circ}$ \\
\hline $\begin{array}{l}(2) \\
\text { Event }\end{array}$ & IPO & $\begin{array}{c}\text { Point of } \\
\text { profitability }\end{array}$ & Death \\
\hline $\begin{array}{c}\text { (3) } \\
\text { Number of Shares } \\
\text { Disposed of }\end{array}$ & $\begin{array}{l}1 / 3 \text { of } \\
\text { original stake }\end{array}$ & $\begin{array}{l}1 / 3 \text { of original } \\
\text { stake }\end{array}$ & $\begin{array}{l}1 / 3 \text { of original } \\
\text { stake }\end{array}$ \\
\hline $\begin{array}{l}(4) \\
\text { Proceeds }\end{array}$ & $\begin{array}{l}\$ 5,000,000 \\
\times 3 \times 1 / 3= \\
\$ 5, \text { OOO, OOO }\end{array}$ & $\begin{array}{l}\$ 5,000,000 \\
\times 9 \times 1 / 3= \\
\$ 15,000,000\end{array}$ & $\begin{array}{l}\$ 5,000,000 \\
\times 18 \times 1 / 3= \\
\$ 30,000,000\end{array}$ \\
\hline $\begin{array}{c}(5) \\
\text { Deductions if } \\
\text { Founders' Stock } \\
\text { Were Used }\end{array}$ & $\$ 0$ & $\$ 0$ & \$o \\
\hline $\begin{array}{c}\text { (6) } \\
\text { Deductions if Stock } \\
\text { Options Were Used }\end{array}$ & $\$ \mathbf{5}, 000,000$ & $\$ 15,000,000$ & $\$ 30,000,000$ \\
\hline $\begin{array}{c}(7) \\
\text { Tax Cost of FS: } \\
{[(6)-(5)] \times 35 \%} \\
\text { starting in Year } 30\end{array}$ & $\$ o^{a}$ & $\begin{array}{c}\$ 20,000,000^{b} \\
\times 35 \%= \\
\$ 7,000,000\end{array}$ & $\begin{array}{c}\$ 30,000,000 \\
\times 35 \%= \\
\$ 10,500,000\end{array}$ \\
\hline $\begin{array}{c}(8) \\
\text { Present Value of } \\
\text { Tax Cost at Time o }\end{array}$ & $\$ 0$ & $\$ 1,218,771$ & $\$ 1,020,8331$ \\
\hline \multicolumn{3}{|c|}{$\begin{array}{l}\text { Total Tax Detriment from Use of Founders' Stock } \\
\text { (Time o dollars) [Sum of the Values in Row 8] }\end{array}$} & $\$ 2,239,604$ \\
\hline
\end{tabular}

a. There are no tax savings in Year 10 because the company is still in a loss position. The deductions from Year 10 carry over to Year 30 and are used then, together with the deductions generated in Year $3^{\circ}$.

b. This value includes $\$ 5$, ,oo, ooo of deductions that carry over from Year 10 and the $\$ 15,000,000$ of deductions from Year 30 . 
V. FALSE START

Table 24: Facts

\begin{tabular}{|c|c|c|c|c|}
\hline $\begin{array}{c}\text { Time } \\
\text { from } \\
\text { Issuance }\end{array}$ & Event & $\begin{array}{c}\text { Stock Value } \\
\text { Relative to } \\
\text { Previous Event } \\
\text { (Annual IRR) }\end{array}$ & $\begin{array}{c}\text { Company } \\
\text { Attained } \\
\text { Profitability? }\end{array}$ & $\begin{array}{c}\text { Stock } \\
\text { Disposition } \\
\text { by Founder? }\end{array}$ \\
\hline 0 & Issuance & N/A & No & No \\
\hline 6 & IPO & 4 Ox $(85 \%)$ & No & $\begin{array}{c}1 / 3 \text { of } \\
\text { original } \\
\text { stake }\end{array}$ \\
\hline 9 & Stock Sale & None (o\%) & No & $\begin{array}{c}1 / 3 \text { of } \\
\text { original } \\
\text { stake }\end{array}$ \\
\hline 12 & Worthless- & ox (N/A) & No & $\begin{array}{c}1 / 3 \text { of } \\
\text { original } \\
\text { stake }\end{array}$ \\
\hline
\end{tabular}


Table 25: Tax Benefit to Founders if Founders' Stock Is Used in Lieu of Options

\begin{tabular}{|c|c|c|c|}
\hline $\begin{array}{l}\text { (1) } \\
\text { Time }\end{array}$ & 6 & 9 & 12 \\
\hline $\begin{array}{l}(2) \\
\text { Event }\end{array}$ & IPO & Stock Sale & Worthlessness \\
\hline $\begin{array}{c}\text { Number of } \\
\text { Shares Disposed } \\
\text { of }\end{array}$ & $\begin{array}{c}1 / 3 \text { of original } \\
\text { stake }\end{array}$ & $\begin{array}{l}\text { 1/3 of original } \\
\text { stake }\end{array}$ & $\begin{array}{c}1 / 3 \text { of original } \\
\text { stake }\end{array}$ \\
\hline $\begin{array}{c}(4) \\
\text { Proceeds }\end{array}$ & $\begin{array}{l}\$ 5,000,000 \\
\times 1 / 3 \times 40= \\
\$ 66,666,667\end{array}$ & $\begin{array}{l}\$ 5,000,000 \\
\times 1 / 3 \times 40= \\
\$ 66,666,667\end{array}$ & $\begin{array}{c}\$ 5,000,000 \\
\times 1 / 3 \times 0= \\
\$ 0\end{array}$ \\
\hline $\begin{array}{c}(5) \\
\text { Tax if Founders' } \\
\text { Stock Were Used }\end{array}$ & $\begin{array}{c}\$ 66,666,667 \times \\
15 \%= \\
\$ 10,000, \text { ooo }\end{array}$ & $\begin{array}{c}\$ 66,666,667 \mathrm{x} \\
15 \%= \\
\$ 10,000,000\end{array}$ & $\begin{array}{c}\$ 0 \times 15 \%= \\
\$ 0\end{array}$ \\
\hline $\begin{array}{c}(6) \\
\text { Tax if Stock } \\
\text { Options Were } \\
\text { Used }\end{array}$ & $\begin{array}{c}\$ 66,666,667 \times \\
37 \cdot 9 \%= \\
\$ 25,266,667\end{array}$ & $\begin{array}{c}\$ 66,666,667 \times \\
37 \cdot 9 \%= \\
\$ 25,266,667\end{array}$ & $\begin{array}{c}\$ 0 \times 37.9 \%= \\
\$ 0\end{array}$ \\
\hline $\begin{array}{c}(7) \\
\text { Tax Savings from } \\
\text { FS } \\
{[(6)-(5)]}\end{array}$ & $\$ 15,266,667$ & $\$_{15}, 266,667$ & $\$ 0$ \\
\hline $\begin{array}{c}(8) \\
\text { Present Value of } \\
\text { Tax Savings at } \\
\text { Time o }\end{array}$ & $\$ 10,762,398$ & $\$ 9,036,317$ & $\$ o$ \\
\hline \multicolumn{3}{|c|}{$\begin{array}{l}\text { Total Tax Benefit from Use of Founders' Stock } \\
\text { (Time o dollars) [Sum of the Values in Row 8] }\end{array}$} & $\$ 19,798,715$ \\
\hline
\end{tabular}


Table 26: Tax Detriment to Company if Founders' Stock Is Used in Lieu of Options

\begin{tabular}{|c|c|c|c|}
\hline $\begin{array}{l}(1) \\
\text { Time }\end{array}$ & 6 & 9 & 12 \\
\hline $\begin{array}{c}(2) \\
\text { Event }\end{array}$ & IPO & Stock Sale & Worthlessness \\
\hline $\begin{array}{c}\text { (3) } \\
\text { Number of Shares } \\
\text { Disposed of }\end{array}$ & $\begin{array}{c}1 / 3 \text { of original } \\
\text { stake }\end{array}$ & $\begin{array}{l}1 / 3 \text { of original } \\
\text { stake }\end{array}$ & $\begin{array}{c}1 / 3 \text { of original } \\
\text { stake }\end{array}$ \\
\hline $\begin{array}{l}(4) \\
\text { Proceeds }\end{array}$ & $\begin{array}{l}\$ 5,000,000 \\
\times 1 / 3 \times 40= \\
\$ 66,666,667\end{array}$ & $\begin{array}{l}\$ 5,000,000 \\
\times 1 / 3 \times 40= \\
\$ 66,666,667\end{array}$ & $\begin{array}{c}\$ 5,000,000 \\
\times 1 / 3 \times 0= \\
\$ 0\end{array}$ \\
\hline $\begin{array}{c}\text { (5) } \\
\text { Deductions if } \\
\text { Founders' Stock } \\
\text { Were Used }\end{array}$ & $\$ 0$ & $\$ 0$ & $\$ 0$ \\
\hline $\begin{array}{c}(6) \\
\text { Deductions if Stock } \\
\text { Options Were Used }\end{array}$ & $\$ 66,666,667$ & $\$ 66,666,667$ & $\$ 0$ \\
\hline $\begin{array}{c}(7) \\
\text { Tax Cost of FS: } \\
{[(6)-(5)] \times 0 \%} \\
\text { because company } \\
\text { never profitable }\end{array}$ & $\begin{array}{c}\$ 66,666,667 \times \\
o \%=\$ o^{\mathrm{a}}\end{array}$ & $\begin{array}{c}\$ 66,666,667 \times \\
\mathbf{o} \%=\$ o^{\mathrm{a}}\end{array}$ & $\$ 0$ \\
\hline $\begin{array}{c}(8) \\
\text { Present Value of } \\
\text { Tax Cost at Time o }\end{array}$ & \$o & $\$ 0$ & $\$ 0$ \\
\hline \multicolumn{3}{|c|}{$\begin{array}{l}\text { Total Tax Detriment from Use of Founders' Stock } \\
\text { (Time o dollars) [Sum of the Values in Row 8] }\end{array}$} & \$o \\
\hline
\end{tabular}

a. There are no tax savings generated because the company never is profitable enough to utilize the net operating losses from the deductions stemming from NQSOs. 
VI. FALSE START CASE WTH REFUNDING OF LOSSES IN YEAR OF LIQUTDATION

Table 27: Facts

\begin{tabular}{|c|c|c|c|c|}
\hline $\begin{array}{c}\text { Time } \\
\text { from } \\
\text { Issuance }\end{array}$ & Event & $\begin{array}{c}\text { Stock Value } \\
\text { Relative to } \\
\text { Previous Event } \\
\text { (Annual IRR) }\end{array}$ & $\begin{array}{c}\text { Company } \\
\text { Attained } \\
\text { Profitability? }\end{array}$ & $\begin{array}{c}\text { Stock } \\
\text { Disposition } \\
\text { by Founder? }\end{array}$ \\
\hline 0 & Issuance & N/A & No & No \\
\hline 6 & IPO & $40 \times(85 \%)$ & No & $\begin{array}{c}1 / 3 \text { of } \\
\text { original } \\
\text { stake }\end{array}$ \\
\hline 9 & Stock Sale & $1 \times(0 \%)$ & No & $\begin{array}{c}1 / 3 \text { of } \\
\text { original } \\
\text { stake }\end{array}$ \\
\hline 12 & $\begin{array}{c}\text { Worthless- } \\
\text { ness }\end{array}$ & ox (N/A) & No & $\begin{array}{c}1 / 3 \text { of } \\
\text { original } \\
\text { stake }\end{array}$ \\
\hline
\end{tabular}


Table 28: Tax Benefit to Founders if Founders' Stock Is Used in Lieu of Options

\begin{tabular}{|c|c|c|c|}
\hline $\begin{array}{c}\text { (1) } \\
\text { Time }\end{array}$ & 6 & 9 & 12 \\
\hline $\begin{array}{c}\text { (2) } \\
\text { Event }\end{array}$ & IPO & Stock Sale & Worthlessness \\
\hline $\begin{array}{c}(\mathbf{3}) \\
\text { Number of } \\
\text { Shares Disposed } \\
\text { of }\end{array}$ & $\begin{array}{l}1 / 3 \text { of original } \\
\text { stake }\end{array}$ & $\begin{array}{l}1 / 3 \text { of original } \\
\text { stake }\end{array}$ & $\begin{array}{l}1 / 3 \text { of original } \\
\text { stake }\end{array}$ \\
\hline $\begin{array}{l}(4) \\
\text { Proceeds }\end{array}$ & $\begin{array}{l}\$ 5,000,000 \\
\times 1 / 3 \times 40= \\
\$ 66,666,667\end{array}$ & $\begin{array}{l}\$ 5,000,000 \\
\times 1 / 3 \times 40= \\
\$ 66,666,667\end{array}$ & $\begin{array}{c}\$ 5,000,000 \\
\times 1 / 3 \times 0= \\
\$ 0\end{array}$ \\
\hline $\begin{array}{c}(\mathbf{5}) \\
\text { Tax if Founders' } \\
\text { Stock Were Used }\end{array}$ & $\begin{array}{c}\$ 66,666,667 \times \\
15 \%= \\
\$ 10,000,000\end{array}$ & $\begin{array}{c}\$ 66,666,667 \times \\
15 \%= \\
\$ 10,000,000\end{array}$ & $\underset{\$ 0}{\$ 0} \times 15 \%=$ \\
\hline $\begin{array}{c}(6) \\
\text { Tax if Stock } \\
\text { Options Were } \\
\text { Used }\end{array}$ & $\begin{array}{c}\$ 66,666,667 \times \\
37 \cdot 9 \%= \\
\$ 25,266,667\end{array}$ & $\begin{array}{c}\$ 66,666,667 \times \\
37 \cdot 9 \%= \\
\$ 25,266,667\end{array}$ & $\begin{array}{l}\text { \$o } \times 37.9 \%= \\
\$ 0\end{array}$ \\
\hline $\begin{array}{c}(7) \\
\text { Tax Savings from } \\
\text { FS } \\
{[(6)-(5)]}\end{array}$ & $\$ 15,266,667$ & $\$ 15,266,667$ & $\$ 0$ \\
\hline $\begin{array}{c}(8) \\
\text { Present Value of } \\
\text { Tax Savings at } \\
\text { Time o }\end{array}$ & $\$ 10,762,398$ & $\$ 9, \circ 36,317$ & $\$ 0$ \\
\hline \multicolumn{3}{|c|}{$\begin{array}{l}\text { Total Tax Benefit from Use of Founders' Stock } \\
\text { (Time o dollars) [Sum of the Values in Row 8] }\end{array}$} & $\$ 19,798,715$ \\
\hline
\end{tabular}


Table 29: Tax Detriment to Company if Founders' Stock Is Used in Lieu of Options

\begin{tabular}{|c|c|c|c|}
\hline $\begin{array}{l}\text { (1) } \\
\text { Time }\end{array}$ & 6 & 9 & 12 \\
\hline $\begin{array}{l}(2) \\
\text { Event }\end{array}$ & IPO & Stock Sale & Worthlessness \\
\hline $\begin{array}{c}(3) \\
\text { Number of Shares } \\
\text { Disposed of }\end{array}$ & $\begin{array}{l}1 / 3 \text { of original } \\
\text { stake }\end{array}$ & $\begin{array}{l}1 / 3 \text { of original } \\
\text { stake }\end{array}$ & $\begin{array}{l}1 / 3 \text { of original } \\
\text { stake }\end{array}$ \\
\hline $\begin{array}{c}(4) \\
\text { Proceeds }\end{array}$ & $\begin{array}{l}\$ 5,000,000 \\
\times 1 / 3 \times 40= \\
\$ 66,666,667\end{array}$ & $\begin{array}{l}\$ 5,000,000 \\
\times 1 / 3 \times 40= \\
\$ 66,666,667\end{array}$ & $\begin{array}{c}\$ 5,000,000 \\
\times 1 / 3 \times 0= \\
\$ 0\end{array}$ \\
\hline $\begin{array}{c}(5) \\
\text { Deductions if } \\
\text { Founders' Stock } \\
\text { Were Used }\end{array}$ & $\$ 0$ & $\$ 0$ & $\$ 0$ \\
\hline $\begin{array}{c}(6) \\
\text { Deductions if Stock } \\
\text { Options Were Used }\end{array}$ & $\$ 66,666,667$ & $\$ 66,666,667$ & $\$ 0$ \\
\hline $\begin{array}{c}(7) \\
\text { Tax Cost of FS: } \\
{[(6)-(5)] \times 35 \%} \\
\text { starting in Year } 12\end{array}$ & $\$ \mathrm{o}^{\mathrm{a}}$ & $\$ o^{a}$ & $\begin{array}{c}\$ 133,333,334^{\mathrm{b}} \\
\times 35 \%= \\
\$ 46,666,667\end{array}$ \\
\hline $\begin{array}{c}(8) \\
\text { Present Value of } \\
\text { Tax Cost at Time o }\end{array}$ & $\$ 0$ & $\$ 0$ & $\$ 23,191,904$ \\
\hline \multicolumn{3}{|c|}{$\begin{array}{l}\text { Total Tax Detriment from Use of Founders' Stock } \\
\text { (Time o dollars) [Sum of the Values in Row 8] }\end{array}$} & $\$ 23,191,904$ \\
\hline
\end{tabular}

a. There are no tax savings generated until Year 12 when the company liquidates and the losses become refundable.

b. This value represents the combination of the Year 6 deductions of $\$ 66,666,667$ plus Year 9 deductions of $\$ 66,666,667$. 
VI. SINGLE WITH INFLATION-ADJUSTED LOSSES

Table 3o: Facts

\begin{tabular}{|c|c|c|c|c|}
\hline $\begin{array}{c}\text { Time } \\
\text { from } \\
\text { Issuance }\end{array}$ & Event & $\begin{array}{c}\text { Stock Value } \\
\text { Relative to } \\
\text { Previous Event } \\
\text { (Annual IRR) }\end{array}$ & $\begin{array}{c}\text { Company } \\
\text { Attained } \\
\text { Profitability? }\end{array}$ & $\begin{array}{c}\text { Stock } \\
\text { Disposition } \\
\text { by Founder? }\end{array}$ \\
\hline o & Issuance & N/A & No & No \\
\hline 10 & IPO & $3 \times(11.6 \%)$ & No & $\begin{array}{c}1 / 3 \text { of } \\
\text { original } \\
\text { stake }\end{array}$ \\
\hline 30 & $\begin{array}{c}\text { Point of } \\
\text { Profitability }\end{array}$ & $3 \times(5 \cdot 7 \%)$ & Yes & $\begin{array}{c}1 / 3 \text { of } \\
\text { original } \\
\text { stake }\end{array}$ \\
\hline 40 & Death & $2 \times(7.2 \%)$ & Yes & $\begin{array}{c}1 / 3 \text { of } \\
\text { original } \\
\text { stake }\end{array}$ \\
\hline
\end{tabular}


Table 31: Tax Benefit to Founders if Founders' Stock Is Used in Lieu of Options

\begin{tabular}{|c|c|c|c|}
\hline $\begin{array}{l}\text { (1) } \\
\text { Time }\end{array}$ & 10 & $3^{\circ}$ & $4^{\circ}$ \\
\hline $\begin{array}{c}(2) \\
\text { Event }\end{array}$ & IPO & $\begin{array}{c}\text { Point of } \\
\text { profitability }\end{array}$ & Death \\
\hline $\begin{array}{c}\text { (3) } \\
\text { Number of } \\
\text { Shares Disposed } \\
\text { of }\end{array}$ & $\begin{array}{l}1 / 3 \text { of original } \\
\text { stake }\end{array}$ & $\begin{array}{l}1 / 3 \text { of original } \\
\text { stake }\end{array}$ & $\begin{array}{c}\text { 1/3 of original } \\
\text { stake }\end{array}$ \\
\hline $\begin{array}{c}(4) \\
\text { Proceeds }\end{array}$ & $\begin{array}{l}\$ 5,000,000 \\
\times 3 \times 1 / 3= \\
\$ 5,000,000\end{array}$ & $\begin{array}{c}\$ 5,000,000 \\
\times 9 \times 1 / 3= \\
\$ 15,000,000\end{array}$ & $\begin{array}{l}\$ 5,000,000 \\
\times 18 \times 1 / 3= \\
\$ 30,000,000\end{array}$ \\
\hline $\begin{array}{c}(\mathbf{5}) \\
\text { Tax if Founders' } \\
\text { Stock Were Used }\end{array}$ & $\begin{array}{c}\$ 5,000,000 \\
\times 15 \%= \\
\$ 750,000\end{array}$ & $\begin{array}{c}\$ 15,000,000 \\
\times 15 \%= \\
\$ 2,250,000\end{array}$ & $\begin{array}{l}\text { \$o (because of } \\
\text { stepped-up } \\
\text { basis at death) }\end{array}$ \\
\hline $\begin{array}{c}(6) \\
\text { Tax if Stock } \\
\text { Options Were } \\
\text { Used }\end{array}$ & $\begin{array}{c}\$ 5,000,000 \\
\times 37 \cdot 9 \%= \\
\$ 1,895, \text { ooo }\end{array}$ & $\begin{array}{c}\$ 15, \text { OOO, Ooo } \\
\times 37.9 \%= \\
\$ 5,685, \text { ooo }\end{array}$ & $\begin{array}{c}\$ 30,000, \text { ooo } \\
\times 37 \cdot 9 \%= \\
\$ 11,370,000\end{array}$ \\
\hline $\begin{array}{c}(7) \\
\text { Tax Savings from } \\
\text { FS } \\
{[(6)-(5)]}\end{array}$ & $\$ 1,145$, OOO & $\$ 3,435,000$ & $\$ 11,37^{0}, 000$ \\
\hline $\begin{array}{c}(8) \\
\text { Present Value of } \\
\text { Tax Savings at } \\
\text { Time o }\end{array}$ & $\$ 639,3^{62}$ & $\$ 59^{8,068}$ & $\$ 1,10_{5}, 4^{16}$ \\
\hline \multicolumn{3}{|c|}{$\begin{array}{l}\text { Total Tax Benefit from Use of Founders' Stock } \\
\text { (Time o dollars) [Sum of the Values in Row 8] }\end{array}$} & $\$ 2,342,846$ \\
\hline
\end{tabular}


Table 32: Tax Detriment to Company if Founders' Stock Is Used in Lieu of Options

\begin{tabular}{|c|c|c|c|}
\hline $\begin{array}{l}(1) \\
\text { Time }\end{array}$ & 10 & $3^{\circ}$ & $4^{\circ}$ \\
\hline $\begin{array}{c}\text { (2) } \\
\text { Event }\end{array}$ & IPO & $\begin{array}{c}\text { Point of } \\
\text { profitability }\end{array}$ & Death \\
\hline $\begin{array}{c}\text { (3) } \\
\text { Number of Shares } \\
\text { Disposed of }\end{array}$ & $\begin{array}{c}1 / 3 \text { of } \\
\text { original stake }\end{array}$ & $\begin{array}{l}\text { 1/3 of original } \\
\text { stake }\end{array}$ & $\begin{array}{l}\text { 1/3 of original } \\
\text { stake }\end{array}$ \\
\hline $\begin{array}{c}(4) \\
\text { Proceeds }\end{array}$ & $\begin{array}{l}\$ 5,000,000 \\
\times 3 \times 1 / 3= \\
\$ 5,000,000\end{array}$ & $\begin{array}{c}\$ 5,000,000 \\
\times 9 \times 1 / 3= \\
\$ 15,000,000\end{array}$ & $\begin{array}{l}\$ 5,000,000 \\
\times 18 \times 1 / 3= \\
\$ 30,000,000\end{array}$ \\
\hline $\begin{array}{c}(5) \\
\text { Deductions if } \\
\text { Founders' Stock } \\
\text { Were Used }\end{array}$ & \$o & $\$ 0$ & $\$ 0$ \\
\hline $\begin{array}{c}(6) \\
\text { Deductions if Stock } \\
\text { Options Were Used }\end{array}$ & $\$ 5,000,000$ & $\$ 15,000,000$ & $\$ 30,000,000$ \\
\hline $\begin{array}{c}(7) \\
\text { Tax Cost of FS: } \\
{[(6)-(5)] \times 35 \%} \\
\text { starting in Year } 3^{\circ} \\
\text { but inflation } \\
\text { adjusted at } 6 \%\end{array}$ & $\$ o^{a}$ & $\begin{array}{l}\$ 31,035,677^{\mathrm{b}} \\
\times 35 \%= \\
\$ 10,862,487\end{array}$ & $\begin{array}{l}\$ 30,000,000 \\
\times 35 \%= \\
\$ 10,500,000\end{array}$ \\
\hline $\begin{array}{c}(8) \\
\text { Present Value of } \\
\text { Tax Cost at Time o }\end{array}$ & \$o & $\$ 1,891,269$ & $\$ 1,020,833^{1}$ \\
\hline \multicolumn{3}{|c|}{$\begin{array}{l}\text { Total Tax Detriment from Use of Founders' Stock } \\
\text { (Time o dollars) [Sum of the Values in Row 8] }\end{array}$} & $\$ 2,912,102$ \\
\hline
\end{tabular}

a. There are no tax savings in Year 10 because the company is still in a loss position. The deductions from Year 10 (plus inflation adjustments) carry over to Year $3^{\circ}$ and are used then, together with the deductions generated in Year 30.

b. This value includes $\$ 5$,ooo,ooo of Year 10 losses inflated at an annual rate of six percent $(\$ 16,035,677)$ and the Year $3^{\circ}$ losses of $\$ 15,000$,ooo. 


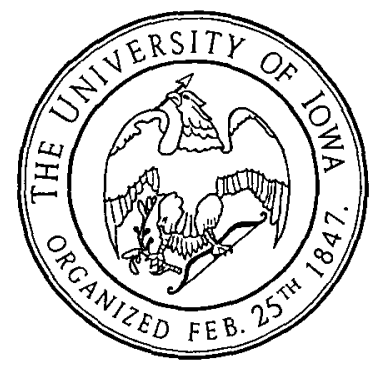

